\title{
Soil nutrient status under upland farming practice in the Lower Northern Thailand
}

\author{
Jaruntorn BoonyanuphaP ${ }^{1, *}$, Katsutoshi SaKURAI ${ }^{2}$ and Sota TanaKa ${ }^{3}$ \\ ${ }^{1}$ The United Graduate School of Agricultural Science, Ehime University, Matsuyama, Ehime 790-8655, Japan \\ ${ }^{2}$ Faculty of Agriculture, Kochi University, Nankoku, Kochi 783-8502, Japan \\ ${ }^{3}$ Graduate School of Kuroshio Science, Kochi University, Nankoku, Kochi 783-8502, Japan \\ * Corresponding author: Jaruntorn BOONYANUPHAP. Tel \& Fax: +81 088864 5178, E-mail: j_boonyanuphap@yahoo.com; \\ charuntornb@hotmail.com
}

\begin{abstract}
In a region of Lower Northern Thailand, the traditional agricultural system has recently been changing toward a more intensive farming system by shortening the fallow cycle and several years of continuous cropping with significant fertilizer application. This study characterized soil fertility levels under the current intensified shifting cultivation systems, by comparison with the fruit tree plantations in the same area and the traditional shifting cultivation systems reported in the previous studies. Soil samples at surface and subsurface layers were collected from thirty study sites. Those study sites were grouped into 4 locations based on topography and parent material. Based on the PCA analysis of soil properties, soil fertility levels were mainly dependent on locations rather than the differences in land use types. However, some of the soils under maize field and fruit tree plantation showed a very low content of organic matter, suggesting occurrence of soil degradation in terms of organic matter. Burning of biomass still played an important role under the current intensified shifting cultivation systems, which brought positive effects to the soil fertility to alleviate soil acidity and supply exchangeable basis and available phosphorus. In contrast, because appreciable amounts of nitrogen seemed to be lost from soil ecosystems during cropping period, appropriate fertilizing methods should be developed to maintain the level of available nitrogen and to prevent environmental pollution.
\end{abstract}

Key Words: upland farming, shifting cultivation, soil fertility, Northern Thailand

\section{INTRODUCTION}

The agricultural system in the upland areas of Thailand is still dependent on shifting cultivation, locally known as Rai lu'an loy or Rai moun wian, which involves slashing and burning of the fallow vegetation in various stages, followed by cultivation for one to several years. In general, shifting cultivation leads to the degradation of soil fertility during the cropping period, whereas the fallow period conventionally serves to restore soil productivity. Successful restoration of soil fertility normally requires a long fallow period for sufficient restoring of soil fertility lost during cropping (Sánchez, 1995). In Thailand, previous major studies had been conducted on a traditional shifting cultivation in the mountainous area with elevation ranging from $500 \mathrm{~m}$ to higher than 1,000 m a.s.l. (Kunstadter et al. 1978; Nakano, 1978; Funakawa et al. 1997a, b; Tanaka et al. 1997; Tanaka et al. 1998 a, b; Tanaka et al. 2001) and an experimental shifting cultivation in which primary forest was burned for upland farming in Northeastern Thailand (Kyuma \& Pairintra, 1983).

In Thung Saleang Luang National Park, Lower Northern Thailand, shifting cultivation has been practiced by Thai people at lower elevation of below $530 \mathrm{~m}$. Due to the changes in socio-economic situation, the traditional system has recently been changing toward a more intensive farming system by shortening the fallow cycle and several years of continuous cropping with significant fertilizer application. Furthermore, fire invasion to the surrounding fallow forest occurs almost every year. The current system with a long continuous cropping may cause lowering soil fertility and land degradation. However, the studies on soil fertility levels and changes under such current shifting cultivation systems were very scarce. On the other hand, attempts for developing a sustainable farming system such as agroforestry 
have been carried out; for example, Tanasombat et al. (2005) recommended paper mulberry plantation for the mountainous area. While such attempts tend to focus on productivity and economic aspects in response to experimental basis, information about soils is rather limited to the evaluation of erosion and the assessment of soil suitability or quality to underpin the sustainable systems. Profound understanding on soil properties under current intensive shifting cultivation systems will provide the clues to solute the problems related to the present upland farming and enhance the development of sustainable systems in terms of soil fertility and organic matter management.

The objective of this study was to obtain basic information about soil fertility status under the current intensified shifting cultivation systems in the Lower Northern Thailand, in comparison with the fruit tree plantations in the same area and the traditional shifting cultivation systems reported in the previous studies.

Although the current system could be almost regarded as a sedentary agricultural system, we referred to the system as 'intensified shifting cultivation system' in this paper, because fallow period seemed to be maintained and indispensable at least for maize cropping (see Table 1).

\section{MATERIALS AND METHODS}

\section{Study area description}

The study area is located in Rom Klao village, which is within the Thung Saleang Luang National Park, Phitsanulok province, Lower Northern Thailand (N16 $43^{\prime}$ to $16^{\circ} 46^{\prime}$ and $\mathrm{E} 100^{\circ} 40^{\prime}$ to $100^{\circ} 43^{\prime}$ ) and had about 50 households (Fig. 1). Topography of the area varies from flat to hilly with an elevation ranging from 280 to 530 $\mathrm{m}$ a.s.l. The slope gradient of the area varies from $0^{\circ}$ to $25^{\circ}$. The local climate was classified as tropical wet and dry or savanna climate or Köppen's Aw (Land Development Department, 1998). The weather data obtained from Thai Meteorological Department during 1992 to 2002 (Thai Meteorological Department, 2002) showing that the mean annual temperature was $27^{\circ} \mathrm{C}$, the mean rainfall was $1,227 \mathrm{~mm}$ per year with mean annual evaporation of 1,695 $\mathrm{mm}, 6$ to 8 months of drought were observed in the year (November to April), and the mean annual humidity was $71 \%$. Climax vegetation types were dry evergreen forest and mixed deciduous forest.

The soils in the village were derived from white to light brown quartz sandstone and shale developed during Jurassic (Mesozoic) period. The soils were mostly classified as Red Yellow Podzolic in the Thai soil classification system (Land Development Department, 1998) or Typic Kandiustults based on the USDA classification system (Soil Survey Staff, 1999).

The study area was mostly covered by agricultural lands, which were mainly used for shifting cultivation and fruit tree plantation. In most of shifting cultivation lands, maize (Zea mays) and cassava (Manihot esculenta Crantz)

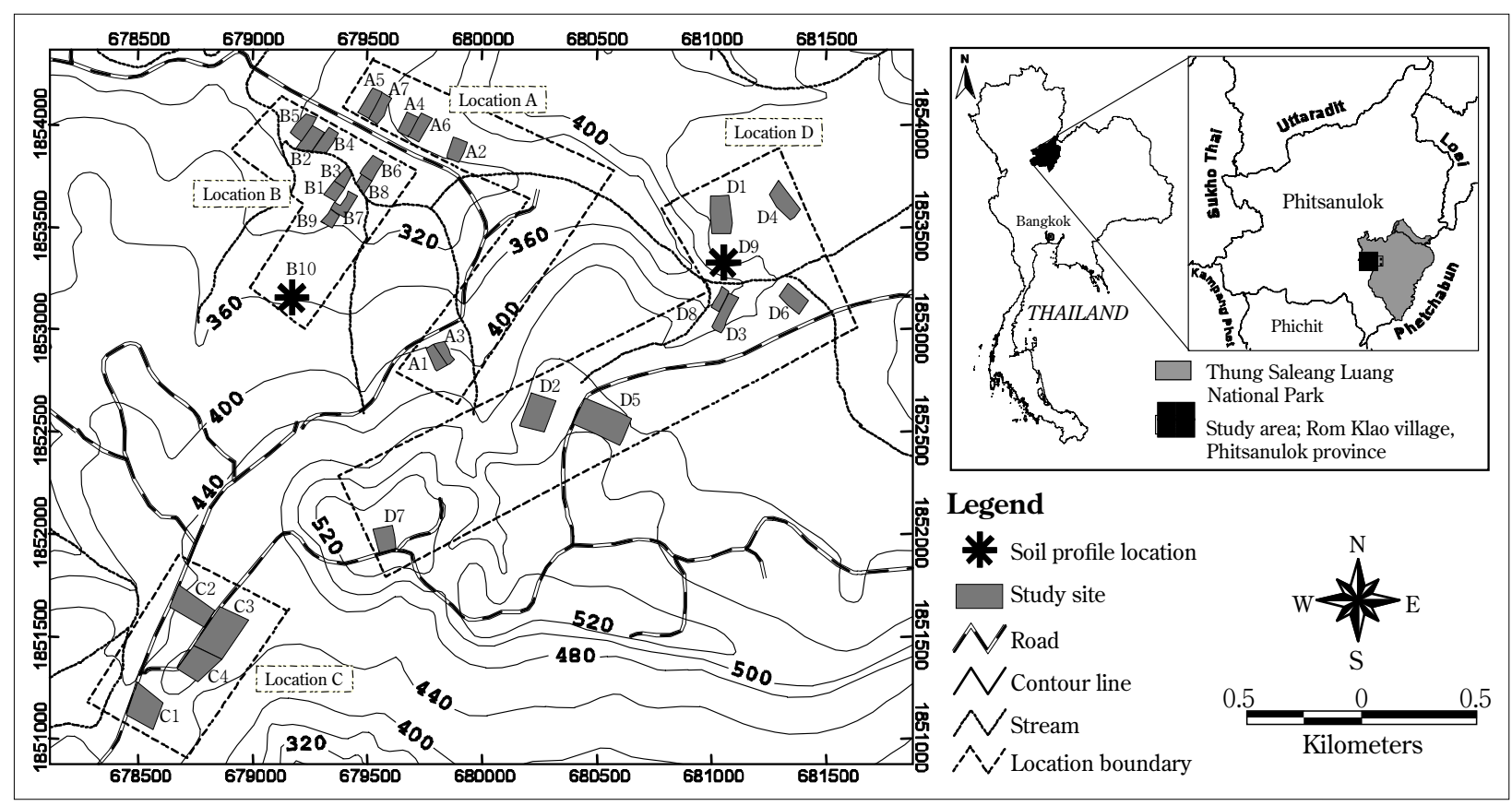

Fig. 1. Location of the study area in Rom Klao Village, Thung Saleang Luang National Park, Phitsanulok, Lower Northern Thailand. 
were cultivated. Compared with traditional shifting cultivation system previously reported, the current intensified shifting cultivation system studied was an irregular system consisting of various fallow periods from one to twenty years with frequent fertilizer application. Decisions to alter the length of a fallow period depend more principally on labor availability than soil fertility recovery. At the middle of March to May, slashing and burning practice is performed for land preparation, and then crops are seeded in the end of May. However, some of these lands are changing to a continuous cultivation or a fruit tree plantation such as mango orchard (Mangifera indica Linn.) and longan orchard (Euphoria longan Lour.). Significant fertilizer application has been common for shifting cultivation as well as the fruit tree plantation although the amount of fertilizer applied depends largely on the farmer's financial condition. In general, for maize cropping by shifting cultivation, a starter fertilizer (commonly 16-20-0) was applied at 150 to $250 \mathrm{~kg} \mathrm{ha}^{-1}$, followed by two times of applications of 46-0-0 (Urea) at 300 to $500 \mathrm{~kg} \mathrm{ha}^{-1}$ in July and August. On the other hand, at longan orchard, a fertilizer 15-15-15 was applied at

Table 1. Sampling site, Slope direction and gradient, and Land use history.

\begin{tabular}{|c|c|c|c|c|c|c|c|c|c|c|c|c|c|c|}
\hline \multirow[t]{2}{*}{ Location } & \multirow{2}{*}{$\begin{array}{l}\text { Site (Slope aspect and } \\
\text { slope gradient) }\end{array}$} & \multicolumn{13}{|c|}{ Land use history year } \\
\hline & & 93 & 94 & 95 & 96 & 97 & 98 & 99 & 00 & 01 & 02 & 03 & 04 & 5 \\
\hline \multirow[t]{7}{*}{$\mathrm{A}$} & MZ-A1 $\left(\mathrm{N} 359^{\circ}, 10^{\circ}\right)$ & & $\mathrm{F}$ & & & & & & $\mathrm{MZ}$ & $\mathrm{MZ}$ & $\mathrm{MZ}$ & LG & $\mathrm{MZ}$ & $\mathrm{MZ}$ \\
\hline & MZ-A2 (SW226, $\left.14^{\circ}\right)$ & & $\mathrm{F}$ & & & & $\mathrm{MZ}$ & & & $\mathrm{F}$ & & $\mathrm{MZ}$ & $\mathrm{MZ}$ & $\mathrm{MZ}$ \\
\hline & LG-A3 (N359 $\left.{ }^{\circ}, 1^{\circ}\right)$ & & $\mathrm{F}$ & & $\mathrm{MZ}$ & $\mathrm{MZ}$ & LG & LG & $\mathrm{LG}$ & $\mathrm{LG}$ & LG & LG & LG & LG \\
\hline & MF-A4 (SW221 $\left.1^{\circ}, 7^{\circ}\right)$ & & $\mathrm{F}$ & $\mathrm{MZ}$ & $\mathrm{MZ}$ & $\mathrm{MZ}$ & & & & $\mathrm{F}$ & & & $\mathrm{F}$ & $\mathrm{MZ}$ \\
\hline & MF-A5 (NW307, $\left.10^{\circ}\right)$ & & $\mathrm{F}$ & $\mathrm{MZ}$ & $\mathrm{MZ}$ & & & & & $\mathrm{F}$ & & & $\mathrm{MZ}$ & $\mathrm{MZ}$ \\
\hline & MF-A6 (SW221, $\left.7^{\circ}\right)$ & & $\mathrm{F}$ & $\mathrm{MZ}$ & $\mathrm{MZ}$ & $\mathrm{MZ}$ & & & & $\mathrm{F}$ & & & $\mathrm{MZ}$ & $\mathrm{CO}$ \\
\hline & LF-A7 (W274ํ․ $\left.9^{\circ}\right)$ & & $\mathrm{F}$ & & & & & & & $\mathrm{F}$ & & & $\mathrm{MZ}$ & $\mathrm{BA}$ \\
\hline \multirow[t]{10}{*}{ B } & $\mathrm{MZ}-\mathrm{B} 1\left(\mathrm{~N} 350^{\circ}, 2^{\circ}\right)$ & & $\mathrm{F}$ & $\mathrm{MZ}$ & $\mathrm{MZ}$ & & & & & $\mathrm{F}$ & & $\mathrm{MZ}$ & $\mathrm{F}$ & $\mathrm{BA}$ \\
\hline & MZ-B2 $\left(\mathrm{W} 263^{\circ}, 4^{\circ}\right)$ & $\mathrm{CA}$ & $\mathrm{CA}$ & $\mathrm{MZ}$ & $\mathrm{MZ}$ & $\mathrm{F}$ & & & & $\mathrm{F}$ & & $\mathrm{MZ}$ & $\mathrm{MZ}$ & $\mathrm{CA}$ \\
\hline & RC-B3 (NW 300, $1^{\circ}$ ) & & $\mathrm{F}$ & & $\mathrm{RC}$ & $\mathrm{RC}$ & & & & $\mathrm{F}$ & & $\mathrm{RC}$ & $\mathrm{BA}$ & BA \\
\hline & 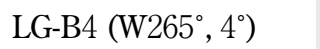 & & $\mathrm{F}$ & & & $\mathrm{MZ}$ & $\mathrm{M} Z$ & LG & $\mathrm{LG}$ & LG & LG & LG & LG & LG \\
\hline & LG-B5 (W275, $\left.4^{\circ}\right)$ & & $\mathrm{F}$ & & & & $\mathrm{MZ}$ & $\mathrm{MZ}$ & LG & LG & LG & LG & LG & LG-BA \\
\hline & LG-B6 $\left(\mathrm{SW} 229^{\circ}, 5^{\circ}\right)$ & & $\mathrm{F}$ & & & LG & LG & LG & LG & LG & LG & LG & LG & LG \\
\hline & SF-B7 $\left(N 6^{\circ}, 9^{\circ}\right)$ & & $\mathrm{F}$ & & & & & $\mathrm{MZ}$ & & $\mathrm{F}$ & & & $\mathrm{MZ}$ & $\mathrm{CA}$ \\
\hline & SF-B8 (Flat, $0^{\circ}$ ) & $\mathrm{CA}$ & $\mathrm{CA}$ & & & $\mathrm{F}$ & & & & $\mathrm{CL}$ & & $\mathrm{F}$ & $\mathrm{MZ}$ & $\mathrm{CA}$ \\
\hline & LF-B9 $\left(\mathrm{N} 350^{\circ}, 5^{\circ}\right)$ & & $\mathrm{F}$ & & & & & & & $\mathrm{F}$ & & & & \\
\hline & DEF-B10 $\left(\mathrm{N} 17^{\circ}, 10^{\circ}\right)$ & & & & & & Natur & l fore & & & & & & \\
\hline \multirow[t]{4}{*}{$\mathrm{C}$} & MG-C1 $\left(\mathrm{N} 11^{\circ}, 5^{\circ}\right)$ & & $\mathrm{F}$ & & MG & MG & MG & MG & MG & MG & MG & MG & MG & MG \\
\hline & $\mathrm{MG}-\mathrm{C} 2\left(\mathrm{NW} 300^{\circ}, 1^{\circ}\right)$ & & $\mathrm{F}$ & & & MG & MG & $\mathrm{MG}$ & MG & MG & MG & MG & MG & MG \\
\hline & MG-C3 $\left(\mathrm{S} 242^{\circ}, 2^{\circ}\right)$ & & $\mathrm{F}$ & & & & & $\mathrm{F}$ & & MG & MG & MG & MG & MG \\
\hline & TP-C4 (Flat, $0^{\circ}$ ) & $\mathrm{MZ}$ & $\mathrm{MZ}$ & $\mathrm{MZ}$ & & & & $\mathrm{F}$ & & & $\mathrm{T}$ & $\mathrm{T}$ & $\mathrm{T}$ & $\mathrm{T}$ \\
\hline \multirow[t]{9}{*}{$\mathrm{D}$} & MZ-D1 $\left(\mathrm{W} 270^{\circ}, 7^{\circ}\right)$ & & & & & & $\mathrm{R}$ & $\mathrm{R}$ & $\mathrm{R}$ & $\mathrm{F}$ & & $\mathrm{MZ}$ & $\mathrm{MZ}$ & $\mathrm{CA}$ \\
\hline & MZ-D2 (NW323, $\left.4^{\circ}\right)$ & $\mathrm{CA}$ & $\mathrm{CA}$ & $\mathrm{CA}$ & $\mathrm{CA}$ & $\mathrm{CA}$ & $\mathrm{CA}$ & & & $\mathrm{F}$ & & $\mathrm{MZ}$ & $\mathrm{F}$ & $\mathrm{F}$ \\
\hline & MZ-D3 (NW328, $\left.19^{\circ}\right)$ & & $\mathrm{F}$ & & & & & & & & $\mathrm{F}$ & $\mathrm{MZ}$ & $\mathrm{MZ}$ & $\mathrm{MZ}$ \\
\hline & MZ-D4 (SW227, $\left.5^{\circ}\right)$ & $\mathrm{F}$ & $\mathrm{MZ}$ & $\mathrm{MZ}$ & $\mathrm{MZ}$ & $\mathrm{MZ}$ & $\mathrm{MZ}$ & $\mathrm{MZ}$ & $\mathrm{MZ}$ & $\mathrm{MZ}$ & $\mathrm{MZ}$ & $\mathrm{MZ}$ & $\mathrm{MZ}$ & $\mathrm{F}$ \\
\hline & MG-D5 $\left(\mathrm{NE} 38^{\circ}, 7^{\circ}\right)$ & MG & MG & MG & MG & MG & MG & MG & MG & MG & MG & MG & MG & MG \\
\hline & MG-D6 $\left(\mathrm{S} 199^{\circ}, 7^{\circ}\right)$ & $\mathrm{F}$ & MG & MG & MG & MG & MG & $\mathrm{MG}$ & MG & MG & MG & MG & MG & MG \\
\hline & MG-D7 (NW327, $\left.9^{\circ}\right)$ & & $\mathrm{F}$ & & & MG & MG & MG & MG & MG & MG & MG & MG & MG \\
\hline & MF-D8 (NW33, $\left.18^{\circ}\right)$ & & & M & M & M & M & $\mathrm{F}$ & & & & & & $\mathrm{F}$ \\
\hline & DEF-D9 (W281, $\left.23^{\circ}\right)$ & & & & & & Natur & l fore & & & & & & \\
\hline
\end{tabular}

F: Natural or Fallow forest; MZ: Maize (CPDK 888); CL: Chili; CA: Cassava; CO: Cotton; RC: Rice; LG: Longan; MG: Mango; TP: Mixed tree plantation; BA: Banana plantation; SF: Short fallow; MF: Medium fallow; LF: Long fallow; DEF: Dry evergreen forest; 
$150 \mathrm{~kg} \mathrm{ha}^{-1} \mathrm{y}^{-1}$ during June to August. A fertilizer 15-15-15 was applied at 180 to $470 \mathrm{~kg} \mathrm{ha}^{-1} \mathrm{y}^{-1}$ in mango orchard sites. In addition, Urea is mainly used as a nitrogen source both in longan and mango orchards, which was applied at $62.5-125 \mathrm{~kg} \mathrm{ha}^{-1} \mathrm{y}^{-1}$. There was no addition of manure throughout the study area except for some mango orchards. Although some of the lands were used permanently, especially for fruit tree plantation (Table 1 ), bunding and terracing were not observed. It should be noted that besides burning for shifting cultivation, the land was usually induced by fire spreading from surrounding area.

\section{Sampling sites}

In March 2004 before cultivation, thirty sites where shifting cultivation and horticulture had been practiced were selected, based on interview with farmers. Land use types of these sites in 2003 were maize field, mango orchard, longan orchard, mixed tree plantation (e.g. Tectona grandis Linn.f., Afzelia xylocarpa Kurz., Hopea odorata Roxb., Pterocarpus macrocarpus Kurz.), short fallow land (1 to 5 years; major plant species: Neyraudia reynaudiana Kunth H., Echinochloa crusgalli L. Beauv., Eupatorium odoratum Linn., Imperala cylindrica L.P. Beauv.), medium fallow land (6 to 10 years; major plant species: Hibiscus cannabinus L. Bambusa spp., Musa acuminate colla.), long fallow land (11 to 20 years; major plant species: Lagerstroemia calyculata Kurz., Sesbaria grandiflora L. Pers., Careya sphaerica Roxb., Bambusa spp., rattan), and natural forest (dry evergreen forest; major plant species: Irvingia malayana Oliv., Pterocarpus macrocarpus Kurz., Dipterocarpus spp., Bambusa spp.). Thereafter, all sampling sites were grouped into 4 locations based on topography and parent materials (Fig. 1 and Table 2). It should be noted that site MF-A4 and MF-D8 were dominated by bamboo showing different nature in soil fertility. Not all types of land use could be studied in each location due to the limitation of land use type availability. The land use history of the sampling sites is summarized in Table 1. Site name was designed based on the type of land use in year 2003.

\section{Soil sampling}

Soil samples were collected from the surface layer (0-5 cm depth) and subsurface layer (20-25 cm depth) at all sites in March before burning. No fire invasion from the surrounding lands yet occurred at this sampling timing. To evaluate the effect of burning on the soil properties, successive soil sampling was carried out at four sites (MZ-A2, MF-A5, LF-A7 and MZ-D3) at six periods within two cropping cycles during year 2004 to 2005, i.e., before burning (March to April), after burning (April to May; before planting and fertilizer application), and after harvest (October to November) in each year. From the field observations, most of the burnt sites were covered with relatively small amount of aboveground biomass such as maize residue or small shrub, it could result in low intensity and short duration of fire under the field condition. In order to avoid heterogeneity in ash distribution and other micro-topographic conditions, all samples were collected in 5 replicates (at the center of the site and 4 points diagonally $5 \mathrm{~m}$ apart from the center) and mixed into one composite sample. Three undisturbed soil samples were collected by a $100 \mathrm{~mL}$ core sampler and used for the determination of bulk density. The soil profile was described at two sites of dry evergreen forest

Table 2. Land use types in 2003 and location characteristics.

\begin{tabular}{|c|c|c|c|c|}
\hline \multirow{2}{*}{$\begin{array}{l}\text { Land use/Characteristics } \\
\text { (cultivating or fallow year) }\end{array}$} & \multicolumn{4}{|c|}{ Number of sampling sites } \\
\hline & Location A & Location B & Location $\mathrm{C}$ & Location D \\
\hline Maize (1-10 years) & 2 & 3 & - & 4 \\
\hline Mango (3-15 years) & - & - & 3 & 3 \\
\hline Longan (4-17 years) & 1 & 3 & - & - \\
\hline Tree plantation (2 years) & - & - & 1 & - \\
\hline Short fallow (1-5 years) & - & 2 & - & - \\
\hline Medium fallow (6-10 years) & 3 & - & - & 1 \\
\hline Long fallow (11-20 years) & 1 & 1 & - & - \\
\hline Natural forest (> 30 years) & - & 1 & - & 1 \\
\hline Elevation (m) & $304-406$ & $280-318$ & $400-441$ & $429-530$ \\
\hline Slope steepness (degree) & $7-14$ & $0-10$ & $0-5$ & $4-23$ \\
\hline Parent materials & sandstone & sandstone & shale \& sandstone & shale \& sandstone \\
\hline
\end{tabular}


(site DEF-B10 and DEF-D9) in March 2004 (Appendix).

\section{Soil analysis}

Soils samples were air-dried and crushed to pass through a sieve with $2 \mathrm{~mm}$ mesh. Roots and other plant debris were removed. Soil $\mathrm{pH}$ in water $\left(\mathrm{pH}\left(\mathrm{H}_{2} \mathrm{O}\right)\right)$ and $1 \mathrm{M}$ $\mathrm{KCl}(\mathrm{pH}(\mathrm{KCl}))$ solution was measured by the glass electrode method, at the soil solution ratio of 1:5 after shaking for 1 hour. Electrical conductivity (EC) was measured after $\mathrm{pH}\left(\mathrm{H}_{2} \mathrm{O}\right)$ measurement. The filtrate from $\mathrm{pH}(\mathrm{KCl})$ measurement was used for exchangeable $\mathrm{Al}$ and $\mathrm{H}$ analysis. Exchangeable acidity $(\mathrm{Al}+\mathrm{H})$ was determined by the titration method with $0.01 \mathrm{M} \mathrm{NaOH}$ and the content of exchangeable $\mathrm{Al}$ with $0.01 \mathrm{M} \mathrm{HCl}$. The content of exchangeable $\mathrm{H}$ was calculated as the difference between the values of the exchangeable acidity and exchangeable Al. Exchangeable ammonium (Exch. $\mathrm{NH}_{4}$ ) was measured by Indophenols method (Mulvaney, 1996) using the filtrate from $\mathrm{pH}(\mathrm{KCl})$ measurement, color developing reagent was added and the NH4 was determined by absorbance measurement with spectrophotometer at a wavelength of $625 \mathrm{~nm}$ (Shimadzu, UV-140-02, Kyoto, Japan). Exchangeable cations (Ca, $\mathrm{Mg}, \mathrm{K}$, and $\mathrm{Na}$ ) were extracted three times with $1 \mathrm{M}$ ammonium acetate at $\mathrm{pH}$ 7.0, and the concentration was measured by atomic absorption spectrophotometer (Shimadzu, AA-6800, Kyoto, Japan). The ammonium ion absorbed in the residue was replaced by $10 \% \mathrm{NaCl}$ and determined with Kjedahl distillation and titration methods as cation exchange capacity (CEC). The available phosphorus (Avail. P) content was measured by Bray II method (Kuo, 1996), where soil samples were extracted with an extracting solution $\left(1 \mathrm{M} \mathrm{NH} \mathrm{N}_{4} \mathrm{~F}\right.$ and $0.5 \mathrm{M} \mathrm{HCl}$ ) then color developing reagent was added and determined available phosphorus by absorbance measurement with spectrophotometer at a wavelength of $710 \mathrm{~nm}$ (Shimadzu, UV-140-02, Kyoto, Japan). The content of total carbon (T-C) and nitrogen (T-N) were analyzed by dry combustion method with NC-Analyzer (Sumigraph NC-80, Sumika Chem. Anal. Service. Osaka, Japan). Particle size distribution was determined by the pipette method (Gee \& Bauder, 1986). Bulk density of the soil was determined using undisturbed soil samples. Data computations and statistical approaches were done using SPSS 10.0 (SPSS Inc.).

\section{RESULTS AND DISCUSSION}

Characterization of soil properties in location

According to Tables 3 and 4, clay contents in surface and subsurface soils were $9.5-34.4 \%$ and $15.6-53.3 \%$, respectively. The clay content of the soils at Location A tended to be high compared with those of other locations although no statistical difference was observed (Table 5). Total carbon content in surface and subsurface soils were $11.2-51.1 \mathrm{~g} \mathrm{~kg}^{-1}$ and $4.5-15.7 \mathrm{~g} \mathrm{~kg}^{-1}$, respectively. Total nitrogen content in surface and subsurface soils were $0.6-5.3 \mathrm{~g} \mathrm{~kg}^{-1}$ and $0.4-1.4 \mathrm{~g} \mathrm{~kg}^{-1}$, respectively. Soil $\mathrm{pH}\left(\mathrm{H}_{2} \mathrm{O}\right)$ was slightly acidic which ranged from 4.3-6.5 and 4.3-5.7 in the surface and subsurface layers, respectively. Exchangeable $\mathrm{Al}$ was high in the subsurface layer. At all Locations, exchangeable $\mathrm{Ca}$ was the dominant exchangeable bases in both layers. The base saturation was generally higher than $50 \%$ in surface soil at Location $\mathrm{A}$ and $\mathrm{B}$. The $\mathrm{Al}$ saturation varied widely, ranging from $0.1-58.2 \%$ and $5.1-96.7 \%$ in surface and subsurface layer, respectively. In subsurface layer at Location $\mathrm{C}$ and $\mathrm{D}$, $\mathrm{Al}$ saturation was very high more than $70 \%$. At Location A, soils in both layers showed higher CEC value than other locations. There were high correlations between CEC and clay content in surface and subsurface layers ( $\mathrm{r}=0.55, P<0.01$ and $\mathrm{r}=0.94, P<0.01$, respectively) and high correlations between $\mathrm{CEC}$ and total carbon content ( $\mathrm{r}=0.87, P<0.01$ and $\mathrm{r}=0.49, P<0.01$, respectively). In addition, there was a high correlation between CEC and the content of exchangeable bases in surface layer $(r=0.87$, $P<0.01)$. Judging from the fact that CEC values were generally higher than sum of exchangeable cations $(\mathrm{Ca}$, $\mathrm{Mg}, \mathrm{K}, \mathrm{Na}$, and $\mathrm{Al}$ ), i.e. effective CEC (ECEC), a certain amount of variable negative charges occurred in the soils (Funakawa et al. 1997a). Haynes and Mokolobate (2001) reported that the contribution of Al to CEC is commonly found in acidic soil with a high $\mathrm{Al}$ saturation, while this study found that the correlation between CEC and $\mathrm{Al}$ saturation was relatively poor $(\mathrm{r}=-0.31, P<0.05$ and $r=-0.18 P<0.05$ at surface and subsurface layers, respectively). Except for Location $\mathrm{C}$, the contents of available phosphorus had a large variation in surface layer, ranging from $3.0-17.0 \mathrm{mg} \mathrm{kg}^{-1}$. Exchangeable $\mathrm{NH}_{4}-\mathrm{N}$ varies among land use types and locations at the surface layer. The soil properties at subsurface layer were similar to those at surface layer, but the differences in the magnitude of values were unclear compared with those of surface soil. Therefore, the properties of surface soils which were more directly affected by land use types will be further analyzed.

In this study, two factors, that is, the locations and land use types were expected to affect soil fertility status. To find key factors that affect the surface soil fertility, the principle component analysis (PCA) was performed 
Table 3. Surface soil properties collected before burning in March 2004 in relation to land use.

\begin{tabular}{|c|c|c|c|c|c|c|c|c|c|c|c|c|c|c|c|c|c|}
\hline \multirow[t]{3}{*}{ Location } & \multirow[t]{3}{*}{ Site } & \multirow{3}{*}{$\begin{array}{c}\mathrm{pH} \\
\left(\mathrm{H}_{2} \mathrm{O}\right)\end{array}$} & \multirow{3}{*}{$\begin{array}{c}\text { T-C } \\
\left(\mathrm{g} \mathrm{kg}^{-1}\right)\end{array}$} & \multirow{3}{*}{$\begin{array}{c}\mathrm{T}-\mathrm{N} \\
\left(\mathrm{g} \mathrm{kg}^{-1}\right)\end{array}$} & \multirow[t]{3}{*}{$\mathrm{CEC}$} & \multicolumn{7}{|c|}{ Exchangeable cations } & \multirow{3}{*}{$\begin{array}{c}\mathrm{Al} \\
\text { saturation } \\
(\%)\end{array}$} & \multirow{3}{*}{$\begin{array}{c}\text { Base } \\
\text { saturation } \\
(\%)\end{array}$} & \multirow{3}{*}{$\begin{array}{c}\text { Avail. P } \\
\left(\mathrm{mg} \mathrm{kg}^{-1}\right)\end{array}$} & \multirow{3}{*}{$\begin{array}{l}\text { Clay } \\
(\%)\end{array}$} & \multirow{3}{*}{$\begin{array}{c}\text { B.D } \\
\left(\mathrm{g} \mathrm{cm}^{-3}\right)\end{array}$} \\
\hline & & & & & & $\mathrm{Ca}$ & $\mathrm{Mg}$ & $\mathrm{K}$ & $\mathrm{Na}$ & $\mathrm{Al}$ & $\mathrm{NH}_{4}-\mathrm{N}$ & ECEC & & & & & \\
\hline & & & & & & \multicolumn{7}{|c|}{$\left(\mathrm{cmol}_{\mathrm{c}} \mathrm{kg}^{-1}\right)$} & & & & & \\
\hline \multirow[t]{6}{*}{ A } & MZ-Al & 5.44 & 29.3 & 2.09 & 18.1 & 8.47 & 2.54 & 0.62 & 0.01 & 0.25 & 0.16 & 11.89 & 2.1 & 64.3 & 6.82 & 34.4 & 1.33 \\
\hline & MZ-A2 & 6.29 & 26.3 & 1.82 & 17.3 & 10.55 & 2.43 & 0.67 & 0.02 & 0.02 & 0.20 & 13.69 & 0.2 & 78.8 & 10.11 & 26.2 & 1.44 \\
\hline & LG-A3 & 5.57 & 24.2 & 1.62 & 14.8 & 6.60 & 2.03 & 0.63 & 0.01 & 0.11 & 0.19 & 9.39 & 1.2 & 62.7 & 8.56 & 26.6 & 1.39 \\
\hline & MF-A4 & 6.46 & 51.1 & 5.33 & 24.8 & 16.27 & 3.76 & 1.31 & 0.13 & 0.03 & 0.21 & 21.49 & 0.1 & 86.5 & 10.07 & 22.9 & 1.42 \\
\hline & MF-A5 & 6.05 & 22.5 & 1.87 & 13.5 & 7.47 & 2.31 & 0.57 & 0.01 & 0.03 & 0.31 & 10.39 & 0.3 & 76.9 & 5.58 & 10.6 & 1.54 \\
\hline & LF-A7 & 5.07 & 17.1 & 1.53 & 13.6 & 3.16 & 1.88 & 0.51 & 0.02 & 0.89 & 0.13 & 6.46 & 13.8 & 40.9 & 3.00 & 32.6 & 1.35 \\
\hline \multirow[t]{10}{*}{ B } & MZ-B1 & 6.02 & 22.9 & 1.78 & 11.8 & 4.86 & 1.42 & 0.72 & 0.01 & 0.08 & 0.13 & 7.09 & 1.2 & 59.6 & 15.94 & 23.4 & 1.43 \\
\hline & MZ-B2 & 6.04 & 10.0 & 0.61 & 5.6 & 2.09 & 0.87 & 0.46 & 0.01 & 0.06 & 0.11 & 3.48 & 1.7 & 60.8 & 6.62 & 12.4 & 1.55 \\
\hline & RC-B3 & 5.85 & 14.5 & 1.11 & 8.2 & 4.65 & 1.36 & 0.3 & 0.03 & 0.02 & 0.08 & 6.37 & 0.4 & 77.4 & 4.78 & 14.3 & 1.53 \\
\hline & LG-B4 & 6.00 & 13.2 & 1.02 & 3.6 & 2.18 & 0.77 & 0.5 & 0.01 & 0.04 & 0.11 & 3.51 & 1.2 & 95.6 & 6.99 & 9.50 & 1.60 \\
\hline & LG-B5 & 5.34 & 19.9 & 1.60 & 9.0 & 2.48 & 0.87 & 0.82 & 0.06 & 0.39 & 0.22 & 4.63 & 8.4 & 47.2 & 4.76 & 22.5 & 1.44 \\
\hline & LG-B6 & 5.72 & 16.5 & 1.39 & 8.2 & 3.29 & 0.99 & 0.59 & 0.01 & 0.11 & 0.22 & 4.99 & 2.2 & 59.3 & 6.71 & 15.0 & 1.52 \\
\hline & SF-B7 & 4.92 & 16.7 & 1.30 & 10.1 & 1.02 & 0.61 & 0.24 & 0.03 & 1.23 & 0.05 & 3.13 & 39.2 & 18.8 & 3.86 & 28.6 & 1.39 \\
\hline & SF-B8 & 4.57 & 14.5 & 1.28 & 7.0 & 2.01 & 0.56 & 0.33 & 0.02 & 0.41 & 0.26 & 3.31 & 12.3 & 41.8 & 16.93 & 19.1 & 1.47 \\
\hline & LF-B9 & 5.34 & 28.3 & 1.80 & 10.6 & 3.97 & 1.74 & 0.45 & 0.08 & 0.11 & 0.12 & 6.35 & 1.8 & 58.7 & 5.56 & 17.6 & 1.48 \\
\hline & DEF-B10 & 5.50 & 22.7 & 1.99 & 12.5 & 3.26 & 1.77 & 0.67 & 0.02 & 0.39 & 0.17 & 6.11 & 6.4 & 45.7 & 6.87 & 23.5 & 1.42 \\
\hline \multirow[t]{4}{*}{$\mathrm{C}$} & MG-C1 & 4.87 & 26.1 & 2.01 & 11.6 & 2.97 & 1.31 & 0.41 & 0.02 & 1.11 & 0.22 & 5.81 & 19.2 & 40.4 & 8.86 & 23.0 & 1.42 \\
\hline & MG-C2 & 4.61 & 25.2 & 1.88 & 9.4 & 1.09 & 0.75 & 0.39 & 0.02 & 0.92 & 0.25 & 3.17 & 29.0 & 23.9 & 11.98 & 20.3 & 1.46 \\
\hline & MG-C3 & 4.66 & 24.3 & 1.83 & 9.3 & 1.35 & 0.94 & 0.82 & 0.02 & 0.97 & 0.40 & 4.10 & 23.7 & 33.7 & 9.66 & 21.6 & 1.44 \\
\hline & TP-C4 & 5.04 & 13.3 & 1.01 & 7.1 & 1.17 & 0.74 & 0.38 & 0.01 & 0.47 & 0.18 & 2.77 & 17.1 & 32.2 & 5.36 & 19.3 & 1.47 \\
\hline \multirow[t]{9}{*}{ D } & MZ-D1 & 4.58 & 11.2 & 0.98 & 8.8 & 0.66 & 0.23 & 0.21 & 0.02 & 1.48 & 0.08 & 2.59 & 56.9 & 12.7 & 4.37 & 21.8 & 1.53 \\
\hline & MZ-D2 & 4.91 & 14.0 & 1.16 & 6.9 & 0.85 & 0.16 & 0.19 & 0.01 & 1.00 & 0.09 & 2.21 & 45.4 & 17.4 & 6.99 & 21.1 & 1.46 \\
\hline & MZ-D3 & 4.77 & 19.5 & 1.47 & 9.6 & 1.21 & 0.33 & 0.41 & 0.01 & 0.87 & 0.09 & 2.84 & 30.7 & 20.6 & 6.60 & 20.6 & 1.47 \\
\hline & MZ-D4 & 4.44 & 12.0 & 0.97 & 8.0 & 1.12 & 0.41 & 0.21 & 0.01 & 1.56 & 0.16 & 3.31 & 47.1 & 22.0 & 5.42 & 19.0 & 1.37 \\
\hline & MG-D5 & 4.70 & 13.5 & 1.10 & 7.6 & 0.79 & 0.33 & 0.31 & 0.01 & 1.59 & 0.19 & 3.03 & 52.4 & 19.0 & 8.84 & 19.5 & 1.47 \\
\hline & MG-D6 & 4.33 & 18.9 & 1.51 & 9.4 & 0.69 & 0.51 & 0.33 & 0.01 & 2.14 & 0.18 & 3.68 & 58.2 & 16.4 & 5.68 & 28.7 & 1.40 \\
\hline & MG-D7 & 5.04 & 18.3 & 1.52 & 7.5 & 1.46 & 0.71 & 0.29 & 0.02 & 0.34 & 0.17 & 2.82 & 12.0 & 33.0 & 7.10 & 16.9 & 1.50 \\
\hline & MF-D8 & 5.44 & 17.1 & 1.31 & 9.8 & 2.43 & 0.91 & 0.44 & 0.08 & 0.22 & 0.16 & 4.09 & 5.4 & 39.4 & 17.03 & 20.8 & 1.46 \\
\hline & DEF-D9 & 4.94 & 30.2 & 2.39 & 13.8 & 1.35 & 0.92 & 0.29 & 0.02 & 1.10 & 0.21 & 3.68 & 30.0 & 18.6 & 3.45 & 29.5 & 1.39 \\
\hline
\end{tabular}

(Table 6 and Fig. 2) by using fifteen soil variables of surface soil. The first three principle component (PC1, PC2, and PC3) accounted for 43.8\%, 22.2\%, and $10.3 \%$ of the variation, respectively. The PC1 had a close negative relation with the basic status and soil organic matter (SOM). The PC2 was associated with clay content, exchangeable $\mathrm{Al}$, and bulk density, whereas, PC3 was related to nitrogen supply as appeared in exchangeable $\mathrm{NH}_{4}-\mathrm{N}$, and $\mathrm{C} / \mathrm{N}$ to a lesser degree.

The ordination diagram of PC1 and PC2 showed most of sites were differentiated by the physico-chemical properties of surface soil. The value of $\mathrm{PC} 1$ axis implies the fertility of the site (Fig. 2). PC1 value tended to be influenced by the location. However, the sites MF-A4 and MF-D8 showed smaller PC1 scores than the other sites in Location A and Location D, respectively, indicating that these sites were the most fertile among the sites within each location. This might be caused by the vigorous growth of bamboo as discussed below. PC2 represented the inherent soil properties derived from parent materials.
The sites in relatively sandy soil area (Location D; Table 5) can be characterized by slightly acidic nature and lower content of clay. Thus, soil fertility in the study area was mainly dependent on the location including topography and parent materials rather than the difference in land use types, which resulted in the large variations of soil properties among locations. The relationship of PC3 was not clear in terms of the location and land use.

\section{Comparison of surface soil properties based on land use type}

The results of surface soil properties relating to land use types were presented in Figure 3. On the whole, there were not clear differences in soil properties observed in terms of land use types within each location. As mentioned above and shown in Table 1, the land use history of the study sites before soil sampling in 2003 varied widely with various amounts of fertilizer applied while fire invasion occurred every year. These factors might affect the soil properties in 2003 and result in a 
Table 4. Subsurface soil properties collected before burning in March 2004 in relation to land use.

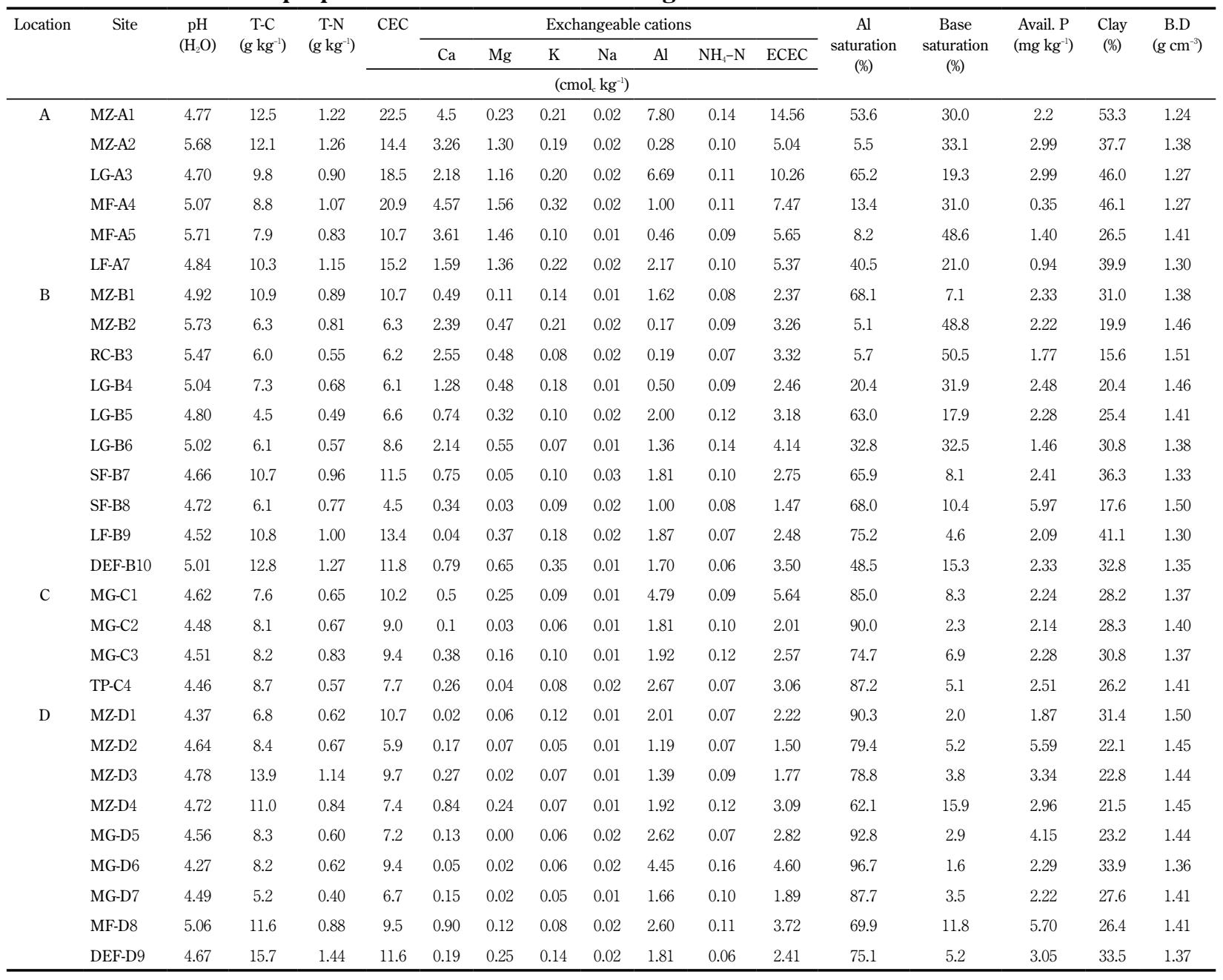

large variation of the properties among study sites even within the same land use type. However, some differences to be noteworthy were observed as follows. In Location B, soil $\mathrm{pH}\left(\mathrm{H}_{2} \mathrm{O}\right)$ was lower under short fallow. In Location $\mathrm{A}$ and $\mathrm{B}, \mathrm{Al}$ saturation was relatively low in general for surface layer, but the soils under fallow at Location $B$ showed a high $\mathrm{Al}$ saturation. This finding agrees with the previous findings on the traditional shifting cultivation in the mountains of Northern Thailand: In the traditional shifting cultivation system, the $\mathrm{pH}$ is usually higher under the crop field than fallow field, because of immediate ash input before maize cultivation, and vigorous uptake of basic cations during fallow (Tanaka et al. 1997). However, under medium fallow fields at Location A and D (site MF-A4 and MF-D8), contents of exchangeable bases were higher than the other sites within each location, resulting in a higher $\mathrm{pH}$ level. This is probably because these sites were mainly covered by bamboo which might accumulate nutrients into the surface soils through rapid pumpingup of nutrients from deeper soils to the surface soils by its vigorous growth during the fallow period. In case of MF-A4, the carbon content was also high, which might be ascribed to the slow decomposition of bamboo litter and the resulting thick organic layer (Christanty et al. 1997). The long fallow fields showed a relatively acidic nature but were not depleted of exchangeable bases probably because of fire invasion occurred every year. Grassland under short fallow resulted to decline in amount of exchangeable bases.

Total carbon contents in the surface layer varied widely among locations as well as within a location (Fig. 3 and Table 3). The contents in Location B and D were significantly lower than those in Location A, indicating the dependency of total carbon on locations. In Location B and D, the soils in some maize and tree plantation sites showed very low levels of total carbon around $10 \mathrm{~g} \mathrm{~kg}^{-1}$, compared with reported values for the traditional shifting cultivation (ex. Funakawa et al. 1997a). This result suggested that under intensified shifting cultivation system and fruit tree plantation in the study 
Table 5. Average value of soil properties collected before burning in March 2004.

\begin{tabular}{|c|c|c|c|c|c|c|c|c|}
\hline Soil properties & $\begin{array}{l}\text { Location A } \\
\quad(n=6)\end{array}$ & & $\begin{array}{c}\text { Location B } \\
(\mathrm{n}=10)\end{array}$ & & $\begin{array}{c}\text { Location C } \\
(\mathrm{n}=4)\end{array}$ & & $\begin{array}{c}\text { Location D } \\
(\mathrm{n}=9)\end{array}$ & \\
\hline \multicolumn{9}{|l|}{ Surface soil $(0-5 \mathrm{~cm})$} \\
\hline $\mathrm{pH}\left(\mathrm{H}_{2} \mathrm{O}\right)$ & $5.8(0.5)$ & $\mathrm{a}$ & $5.5(0.5)$ & $\mathrm{a}$ & $4.8(0.0)$ & $\mathrm{b}$ & $4.8(0.3)$ & $\mathrm{b}$ \\
\hline $\mathrm{pH}(\mathrm{KCl})$ & $4.8(1.0)$ & $\mathrm{a}$ & $4.5(0.5)$ & $a b$ & $3.9(0.1)$ & $\mathrm{b}$ & $3.9(0.3)$ & $\mathrm{b}$ \\
\hline $\mathrm{EC}\left(\mathrm{mS} \mathrm{m}^{-1}\right)$ & $4.9(1.8)$ & $\mathrm{a}$ & $2.8(1.7)$ & $\mathrm{ab}$ & $2.1(0.6)$ & $\mathrm{b}$ & $2.4(1.4)$ & $\mathrm{b}$ \\
\hline T-C $\left(\mathrm{g} \mathrm{kg}^{-1}\right)$ & $28.4(11.8)$ & $\mathrm{a}$ & $17.9(5.5)$ & $\mathrm{b}$ & $22.2(6.0)$ & $a b$ & $17.2(5.8)$ & $\mathrm{b}$ \\
\hline $\mathrm{T}-\mathrm{N}\left(\mathrm{g} \mathrm{kg}^{-1}\right)$ & $2.4(1.5)$ & $\mathrm{a}$ & $1.4(0.4)$ & $\mathrm{b}$ & $1.7(0.5)$ & $a b$ & $1.4(0.4)$ & $\mathrm{b}$ \\
\hline $\mathrm{C} / \mathrm{N}$ & $12.7(2.1)$ & ns & $13.1(1.7)$ & ns & $13.2(0.2)$ & ns & $12.4(0.6)$ & ns \\
\hline Clay (\%) & $25.6(8.5)$ & $\mathrm{a}$ & $18.7(5.9)$ & $\mathrm{b}$ & $21.1(1.6)$ & $a b$ & $22.0(4.3)$ & $\mathrm{ab}$ \\
\hline Silt (\%) & $22.5(5.8)$ & $\mathrm{a}$ & $11.6(9.1)$ & $\mathrm{bc}$ & $13.4(5.8)$ & $\mathrm{b}$ & $7.7(5.3)$ & $\mathrm{c}$ \\
\hline Sand (\%) & $52.0(5.8)$ & $\mathrm{b}$ & $69.9(9.1)$ & $\mathrm{a}$ & $65.6(5.8)$ & $\mathrm{a}$ & $70.2(5.3)$ & $\mathrm{a}$ \\
\hline $\mathrm{CEC}\left(\mathrm{cmol}_{\mathrm{c}} \mathrm{kg}^{-1}\right)$ & $17.0(4.4)$ & $\mathrm{a}$ & $8.7(2.8)$ & $\mathrm{b}$ & $9.4(1.8)$ & $\mathrm{b}$ & $9.0(2.1)$ & $\mathrm{b}$ \\
\hline Exch. Ca $\left(\mathrm{cmol}_{\mathrm{c}} \mathrm{kg}^{-1}\right)$ & $8.75(4.41)$ & $\mathrm{a}$ & $2.98(1.24)$ & $\mathrm{b}$ & $1.65(0.89)$ & $\mathrm{b}$ & $1.17(0.65)$ & $\mathrm{b}$ \\
\hline Exch. $\mathrm{Mg}\left(\mathrm{cmol}_{\mathrm{c}} \mathrm{kg}^{-1}\right)$ & $2.49(0.67)$ & $\mathrm{a}$ & $1.10(0.45)$ & $\mathrm{b}$ & $0.93(0.26)$ & $\mathrm{bc}$ & $0.50(0.28)$ & $\mathrm{c}$ \\
\hline Exch. K $\left(\mathrm{cmol}_{\mathrm{c}} \mathrm{kg}^{-1}\right)$ & $0.72(0.29)$ & $\mathrm{a}$ & $0.51(0.19)$ & $\mathrm{ab}$ & $0.50(0.21)$ & $a b$ & $0.30(0.09)$ & $\mathrm{b}$ \\
\hline Exch. $\mathrm{Na}\left(\mathrm{cmol}_{\mathrm{c}} \mathrm{kg}^{-1}\right)$ & $0.03(0.04)$ & ns & $0.03(0.02)$ & ns & $0.02(0.0)$ & ns & $0.02(0.02)$ & ns \\
\hline Exch. $\mathrm{NH}_{4}-\mathrm{N}\left(\mathrm{cmol}_{\mathrm{c}} \mathrm{kg}^{-1}\right)$ & $0.20(0.06)$ & $\mathrm{ab}$ & $0.15(0.07)$ & $\mathrm{b}$ & $0.27(0.10)$ & $\mathrm{a}$ & $0.15(0.05)$ & $\mathrm{b}$ \\
\hline Exch. Al $\left(\mathrm{cmol}_{\mathrm{c}} \mathrm{kg}^{-1}\right)$ & $0.2(0.3)$ & $\mathrm{b}$ & $0.3(0.4)$ & $\mathrm{b}$ & $0.9(0.3)$ & a & $1.1(0.62)$ & $\mathrm{a}$ \\
\hline Exch. H $\left(\mathrm{cmol}_{\mathrm{c}} \mathrm{kg}^{-1}\right)$ & $0.2(0.4)$ & ns & $0.2(0.4)$ & ns & $0.4(0.08)$ & ns & $0.7(0.7)$ & ns \\
\hline Sum of exch. Bases $\left(\mathrm{cmol}_{\mathrm{c}} \mathrm{kg}^{-1}\right)$ & $12.0(5.4)$ & $\mathrm{a}$ & $4.6(1.7)$ & $\mathrm{b}$ & $3.1(1.1)$ & $\mathrm{b}$ & $5.1(4.5)$ & $\mathrm{b}$ \\
\hline $\operatorname{ECEC~}\left(\mathrm{cmol}_{\mathrm{c}} \mathrm{kg}^{-1}\right)$ & $12.2(5.2)$ & $\mathrm{a}$ & $4.9(1.5)$ & $\mathrm{b}$ & $4.0(1.4)$ & $\mathrm{b}$ & $3.1(0.6)$ & $\mathrm{b}$ \\
\hline Avail. P (mg P kg ${ }^{-1}$ ) & $7.4(2.8)$ & ns & $7.9(4.6)$ & ns & $9.0(2.7)$ & ns & $7.3(4.0)$ & ns \\
\hline Base saturation (\%) & $68.3(16.2)$ & $\mathrm{a}$ & $56.5(20.7)$ & $\mathrm{ab}$ & $32.6(6.8)$ & bc & $22.1(8.56)$ & $\mathrm{c}$ \\
\hline Al saturation (\%) & $2.9(5.4)$ & $\mathrm{c}$ & $7.5(11.8)$ & $\mathrm{bc}$ & $22.2(5.3)$ & $a b$ & $37.6(19.2)$ & $\mathrm{a}$ \\
\hline Bulk density $\left(\mathrm{g} \mathrm{cm}^{-3}\right)$ & $1.41(0.08)$ & ns & $1.48(0.07)$ & ns & $1.45(0.02)$ & ns & $1.45(0.05)$ & ns \\
\hline \multicolumn{9}{|l|}{ Subsurface soil $(20-25 \mathrm{~cm})$} \\
\hline $\mathrm{pH}\left(\mathrm{H}_{2} \mathrm{O}\right)$ & $5.1(0.5)$ & $\mathrm{a}$ & $5.0(0.3)$ & $\mathrm{ab}$ & $4.5(0.0)$ & $\mathrm{c}$ & $4.6(0.2)$ & bc \\
\hline $\mathrm{pH}(\mathrm{KCl})$ & $3.7(0.3)$ & ns & $3.8(0.2)$ & ns & $3.7(0.0)$ & ns & $3.7(0.1)$ & ns \\
\hline $\mathrm{EC}\left(\mathrm{mS} \mathrm{m}^{-1}\right)$ & $0.8(0.1)$ & ns & $0.9(0.6)$ & ns & $0.6(0.1)$ & ns & $1.0(0.8)$ & ns \\
\hline T-C $\left(\mathrm{g} \mathrm{kg}^{-1}\right)$ & $10.2(1.8)$ & ns & $8.1(2.9)$ & $\mathrm{ns}$ & $8.1(0.4)$ & ns & $9.9(3.4)$ & ns \\
\hline $\mathrm{T}-\mathrm{N}\left(\mathrm{g} \mathrm{kg}^{-1}\right)$ & $1.1(0.2)$ & $\mathrm{a}$ & $0.8(0.2)$ & $\mathrm{ab}$ & $0.7(0.1)$ & $\mathrm{b}$ & $0.8(0.3)$ & $a b$ \\
\hline $\mathrm{C} / \mathrm{N}$ & $9.5(0.9)$ & $\mathrm{b}$ & $10.1(1.4)$ & $\mathrm{b}$ & $12.3(2.3)$ & $\mathrm{a}$ & $12.6(1.1)$ & $\mathrm{a}$ \\
\hline Clay (\%) & $41.6(9.2)$ & $\mathrm{a}$ & $27.1(8.6)$ & $\mathrm{b}$ & $28.4(1.9)$ & $\mathrm{b}$ & $26.9(5.0)$ & $\mathrm{b}$ \\
\hline Silt (\%) & $19.3(4.6)$ & $\mathrm{a}$ & $12.1(4.1)$ & $\mathrm{bc}$ & $14.5(6.0)$ & $\mathrm{b}$ & $9.3(2.2)$ & $\mathrm{c}$ \\
\hline Sand (\%) & $39.1(12.6)$ & $\mathrm{b}$ & $60.8(12.1)$ & $\mathrm{a}$ & $57.2(6.8)$ & $\mathrm{a}$ & $63.8(5.7)$ & $\mathrm{a}$ \\
\hline $\mathrm{CEC}\left(\mathrm{cmol}_{\mathrm{c}} \mathrm{kg}^{-1}\right)$ & $17.0(4.4)$ & $\mathrm{a}$ & $8.6(3.0)$ & $\mathrm{b}$ & $9.1(1.1)$ & $b$ & $8.7(1.9)$ & $\mathrm{b}$ \\
\hline Exch. Ca $\left(\mathrm{cmol}_{\mathrm{c}} \mathrm{kg}^{-1}\right)$ & $3.29(1.21)$ & $\mathrm{a}$ & $1.15(0.90)$ & $\mathrm{b}$ & $0.31(0.17)$ & $\mathrm{b}$ & $0.30(0.33)$ & $\mathrm{b}$ \\
\hline Exch. $\mathrm{Mg}\left(\mathrm{cmol}_{\mathrm{c}} \mathrm{kg}^{-1}\right)$ & $1.48(0.30)$ & $\mathrm{a}$ & $0.35(0.22)$ & $\mathrm{b}$ & $0.12(0.10)$ & $\mathrm{c}$ & $0.09(0.15)$ & $\mathrm{c}$ \\
\hline Exch. K $\left(\mathrm{cmol}_{\mathrm{c}} \mathrm{kg}^{-1}\right)$ & $0.21(0.07)$ & a & $0.15(0.09)$ & $\mathrm{ab}$ & $0.81(0.02)$ & $\mathrm{b}$ & $0.08(0.03)$ & $\mathrm{b}$ \\
\hline Exch. $\mathrm{Na}\left(\mathrm{cmol}_{\mathrm{c}} \mathrm{kg}^{-1}\right)$ & $0.02(0.01)$ & ns & $0.02(0.01)$ & ns & $0.01(0.02)$ & ns & $0.01(0.02)$ & ns \\
\hline Exch. $\mathrm{NH}_{4}-\mathrm{N}\left(\mathrm{cmol}_{\mathrm{c}} \mathrm{kg}^{-1}\right)$ & $0.11(0.02)$ & ns & $0.09(0.02)$ & ns & $0.10(0.02)$ & ns & $0.09(0.03)$ & ns \\
\hline Exch. Al $\left(\mathrm{cmol}_{\mathrm{c}} \mathrm{kg}^{-1}\right)$ & $3.1(3.3)$ & ns & $1.2(0.7)$ & ns & $2.8(1.4)$ & ns & $2.2(1.0)$ & ns \\
\hline Exch. $\mathrm{H}\left(\mathrm{cmol}_{\mathrm{c}} \mathrm{kg}^{-1}\right)$ & $1.2(1.6)$ & ns & $1.3(1.7)$ & $\mathrm{ns}$ & $1.3(0.70)$ & ns & $1.2(1.2)$ & ns \\
\hline Sum of exch. Bases $\left(\mathrm{cmol}_{\mathrm{c}} \mathrm{kg}^{-1}\right)$ & $5.0(1.5)$ & $\mathrm{a}$ & $1.7(1.0)$ & $\mathrm{b}$ & $0.5(0.3)$ & $\mathrm{c}$ & $0.5(0.4)$ & $\mathrm{c}$ \\
\hline $\mathrm{ECEC}\left(\mathrm{cmol}_{\mathrm{c}} \mathrm{kg}^{-1}\right)$ & $8.1(3.7)$ & $\mathrm{a}$ & $2.9(0.6)$ & $\mathrm{b}$ & $3.3(1.6)$ & $\mathrm{b}$ & $2.7(1.0)$ & $\mathrm{b}$ \\
\hline Avail. P (mg P kg ${ }^{-1}$ ) & $1.8(1.1)$ & $\mathrm{b}$ & $2.5(1.3)$ & $\mathrm{ab}$ & $2.3(0.2)$ & $a b$ & $3.46(1.4)$ & $\mathrm{a}$ \\
\hline Base saturation (\%) & 30.5 (10.5) & $\mathrm{a}$ & $22.7(17.2)$ & $\mathrm{a}$ & $5.6(2.6)$ & $\mathrm{b}$ & $5.7(4.8)$ & $\mathrm{b}$ \\
\hline Al saturation (\%) & $31.1(25.5)$ & $\mathrm{b}$ & $45.3(27.2)$ & $\mathrm{b}$ & $84.2(6.68)$ & $\mathrm{a}$ & $81.4(11.4)$ & $\mathrm{a}$ \\
\hline Bulk density $\left(\mathrm{g} \mathrm{cm}^{-3}\right)$ & $1.31(0.07)$ & $\mathrm{b}$ & $1.40(0.07)$ & $\mathrm{a}$ & $1.39(0.02)$ & $\mathrm{a}$ & $1.43(0.04)$ & $\mathrm{a}$ \\
\hline
\end{tabular}

Parentheses indicate standard deviation; different letters in same row indicate significant differences among locations (Duncan's test, $p<0.05$ ); ns, not significant; Sum of exch. Bases, Exch. $\mathrm{Ca}+\mathrm{Mg}+\mathrm{K}+\mathrm{Na}$; ECEC, Exch. $\mathrm{Ca}+\mathrm{Mg}+\mathrm{K}+\mathrm{Na}+\mathrm{Al}$; $\mathrm{Al}$ saturation, $(\mathrm{Exch} . \mathrm{Al} / \mathrm{ECEC}) \times 100$ 


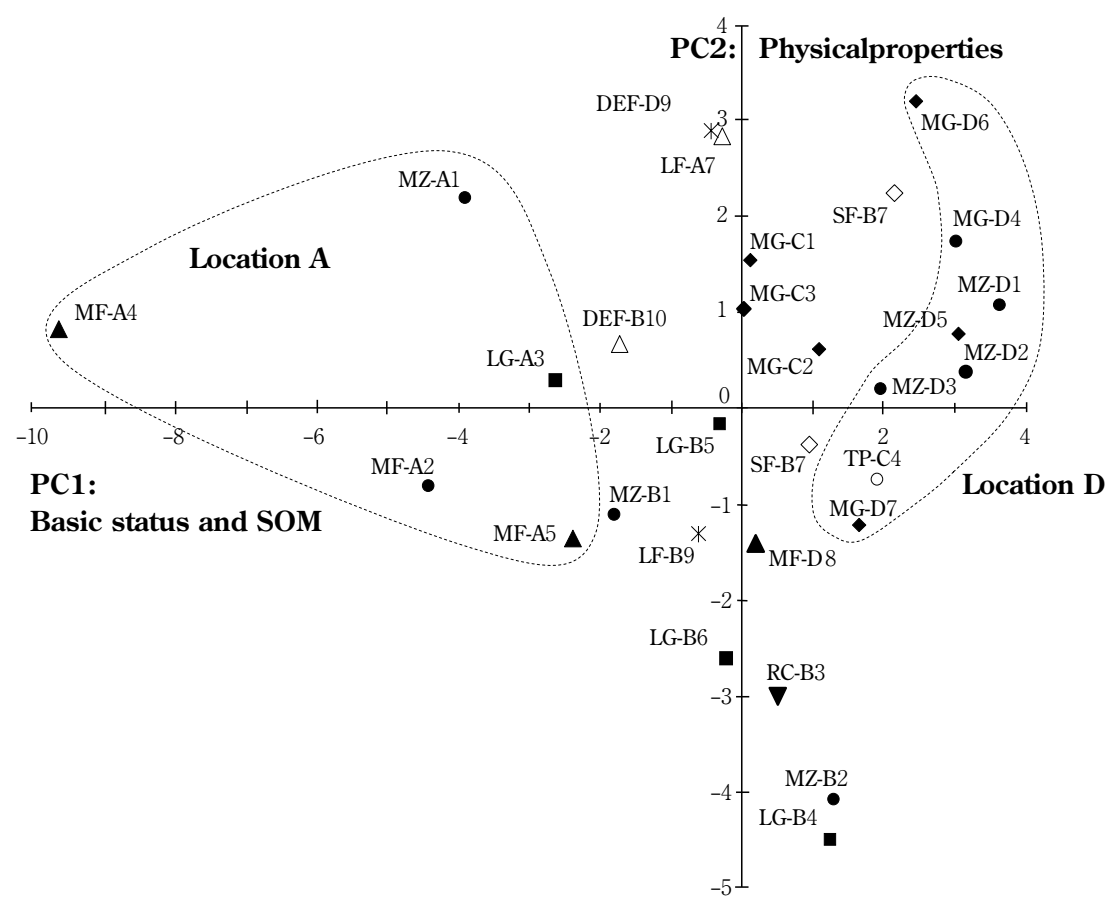

Fig. 2. PCA ordination diagram of PC1 and PC2 showing variation in surface soil properties of study site. - maize field; $\nabla$, rice field; $\checkmark$, mango orchard; $\square$, longan orchard; $\bigcirc$, tree plantation; $\diamond$, short fallow; $\Delta$, medium fallow; $\chi$, long fallow; $\triangle$, dry evergreen forest.

Table 6. Soil parameters used for PCA and results of PCA of the surface soils collected before burning in March 2004.

Variables analyzed

pH $\left(\mathrm{H}_{2} \mathrm{O}\right)$, EC, T-C, T-N, C/N, CEC, Exch. Ca, Exch. Mg, Exch. K, Exch. Al, Exch. $\mathrm{NH}_{4}-\mathrm{N}, \mathrm{Al}$ saturation, Avail. P, Clay content, and Bulk density

\begin{tabular}{|c|c|c|c|c|}
\hline & Value & $\mathrm{PC} 1$ & $\mathrm{PC} 2$ & PC3 \\
\hline \multirow{2}{*}{$\begin{array}{l}\text { Variables with a high } \\
\text { Factor loading }(>0.7)\end{array}$} & \multirow{2}{*}{$\begin{array}{l}+ \\
+\end{array}$} & & Clay content and Exch. Al, & Exch. $\mathrm{NH}_{4}-\mathrm{N}$ \\
\hline & & $\begin{array}{l}\text { Exch. Mg, Exch. Ca, CEC, } \\
\text { Exch. K, T-C, T-N, pH }\left(\mathrm{H}_{2} \mathrm{O}\right)\end{array}$ & Bulk density & $\mathrm{C} / \mathrm{N}$ (factor loading $=0.53$ ) \\
\hline Contribution & & $43.8 \%$ & $22.2 \%$ & $10.3 \%$ \\
\hline Name of PC axis & & Basic status and SOM & Physical properties & N supply \\
\hline
\end{tabular}

area, in some cases, soil organic matter may decrease rapidly and severely due to the loss through vigorous decomposition process and small input as litterfall under poor vegetation. According to Funakawa et al. (1997b), it was estimated that about $10 \%$ of organic matter stored in the upper $50 \mathrm{~cm}$ of soil layers was decomposed within one year in upland crop fields and, as a result, soil organic matter markedly decreased under continuous cropping. However, the comparison of total carbon contents with landuse history shown in Table 1 could not provide any clear evidence about the influences of continuous cropping for several years on the level of soil organic matter. Available phosphorus content at mango orchards in Location $\mathrm{C}\left(8.86-11.98 \mathrm{mg} \mathrm{kg}{ }^{-1} 1\right)$ was higher than that in mixed tree plantation $\left(5.36 \mathrm{mg} \mathrm{kg}^{-1}\right)$, partially due to the annual fertilizer application.

\section{Effects of burning and fertilizer application on} surface soil properties for maize cropping

The changes in $\mathrm{pH}$ and major nutrients in surface soils after burning are shown in Table 7 and Figure 4. Results showed no consistent tendency of total carbon content 

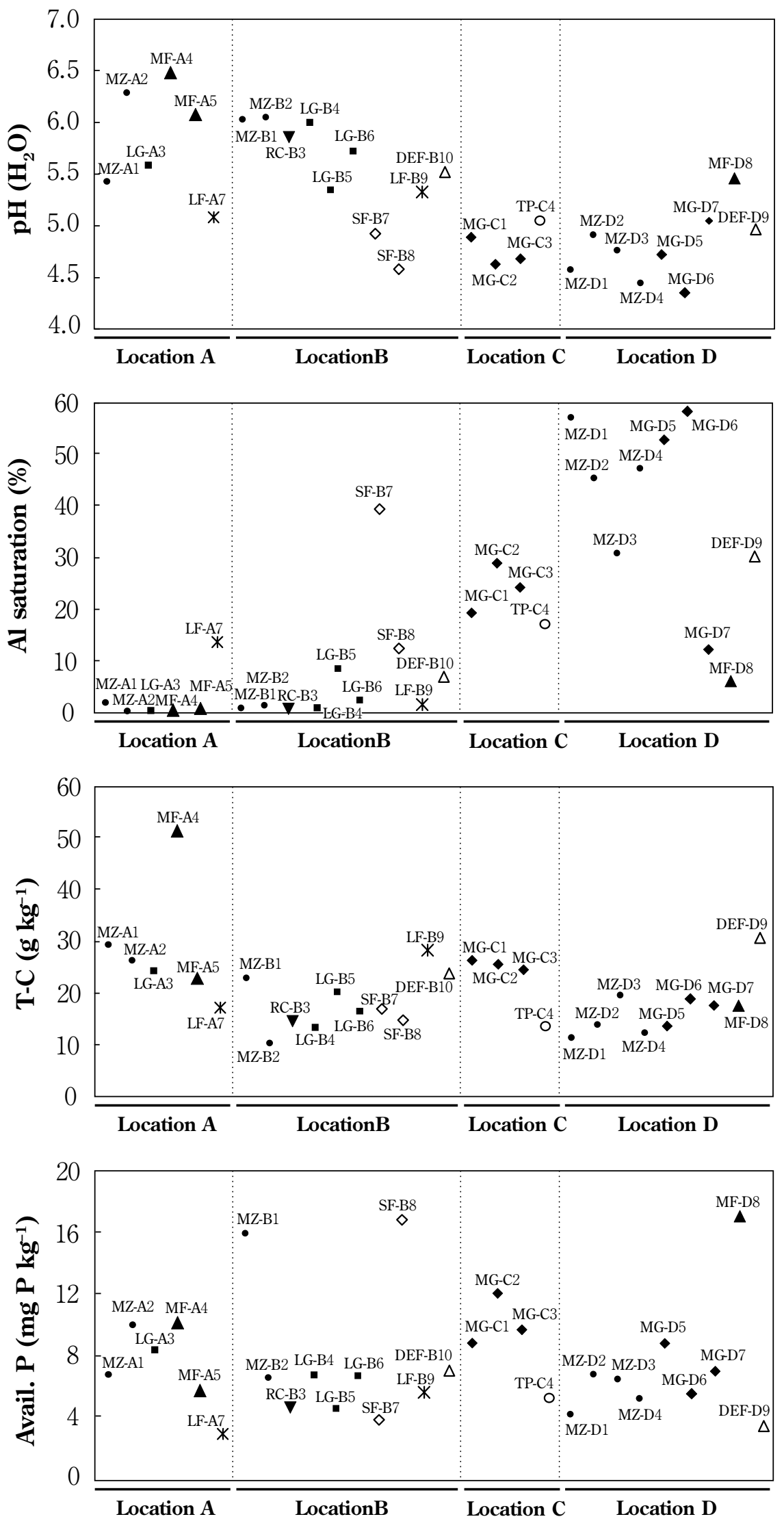

Fig. 3. Soil properties at the depth of surface $0-5 \mathrm{~cm}$ collected before burning in March 2004. See footnote in Fig. 2. 

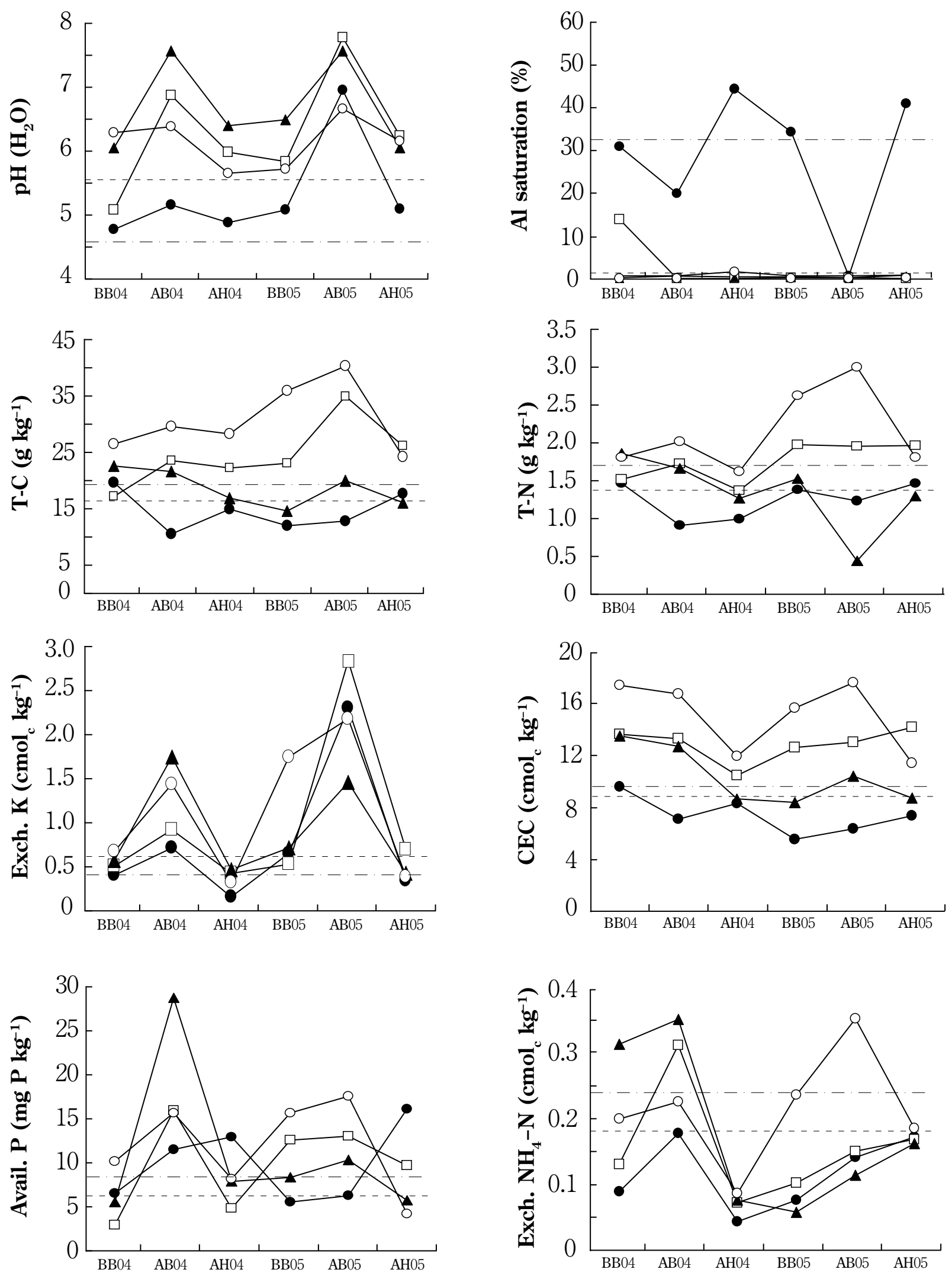

Fig. 4. Changes in fertility characters of surface soil by burning under shifting cultivation fields; BB04, before burning in 2004; AB04, after burning in 2004; AH04, after harvest; BB05, before burning 2005; AB05, after burning 2005; AH05, after harvest 2005. $\bigcirc$, MZ-A2; $\triangle$, MF-A5; $\square$, LF-A7; O, MZ-D3; - _. - , average value of mango orchard; - . . - average value of longan orchard. 
Table 7. Change in soil properties by burning.

\begin{tabular}{|c|c|c|c|c|c|c|c|c|c|c|c|c|c|c|c|c|}
\hline \multirow{3}{*}{ Soil property } & \multicolumn{4}{|c|}{ Site MZ-A2 } & \multicolumn{4}{|c|}{ Site MF-A5 } & \multicolumn{4}{|c|}{ Site LF-A7 } & \multicolumn{4}{|c|}{ Site MZ-D3 } \\
\hline & \multicolumn{2}{|c|}{ 1st burning } & \multicolumn{2}{|c|}{ 2nd burning } & \multicolumn{2}{|c|}{ 1st burning } & \multicolumn{2}{|c|}{ 2nd burning } & \multicolumn{2}{|c|}{ 1st burning } & \multicolumn{2}{|c|}{ 2nd burning } & \multicolumn{2}{|c|}{ 1st burning } & \multicolumn{2}{|c|}{ 2nd burning } \\
\hline & Before & After & Before & After & Before & After & Before & After & Before & After & Before & After & Before & After & Before & After \\
\hline \multicolumn{17}{|l|}{ Surface soil } \\
\hline $\mathrm{pH}\left(\mathrm{H}_{2} \mathrm{O}\right)$ & 6.29 & 6.38 & 5.72 & 6.66 & 6.05 & 7.56 & 6.49 & 7.56 & 5.07 & 6.87 & 5.83 & 7.77 & 4.77 & 5.15 & 5.08 & 6.95 \\
\hline $\mathrm{T}-\mathrm{C}\left(\mathrm{g} \mathrm{kg}^{-1}\right)$ & 26.3 & 29.4 & 35.8 & 40.1 & 22.48 & 21.50 & 14.4 & 19.8 & 17.1 & 23.4 & 22.9 & 34.7 & 19.5 & 10.4 & 11.8 & 12.6 \\
\hline T-N $\left(\mathrm{g} \mathrm{kg}^{-1}\right)$ & 1.82 & 2.03 & 2.63 & 3.00 & 1.87 & 1.67 & 1.54 & 0.46 & 1.53 & 1.73 & 1.98 & 1.96 & 1.47 & 0.93 & 1.39 & 1.25 \\
\hline $\mathrm{C} / \mathrm{N}$ & 14.45 & 14.48 & 13.61 & 13.37 & 12.02 & 12.87 & 9.35 & 43.04 & 11.18 & 13.53 & 11.57 & 17.70 & 13.27 & 11.18 & 8.49 & 10.08 \\
\hline $\mathrm{CEC}\left(\mathrm{cmol}_{\mathrm{c}} \mathrm{kg}^{-1}\right)$ & 17.3 & 16.7 & 15.7 & 17.6 & 13.5 & 12.7 & 8.4 & 10.4 & 13.6 & 13.3 & 12.6 & 13.0 & 9.6 & 7.1 & 5.5 & 6.3 \\
\hline Exch. Ca $\left(\mathrm{cmol}_{\mathrm{c}} \mathrm{kg}^{-1}\right)$ & 10.55 & 8.79 & 6.10 & 10.21 & 7.47 & 12.18 & 5.55 & 11.92 & 3.16 & 8.85 & 6.75 & 10.64 & 1.21 & 0.87 & 0.51 & 1.96 \\
\hline Exch. $\mathrm{Mg}\left(\mathrm{cmol}_{\mathrm{c}} \mathrm{kg}^{-1}\right)$ & 2.43 & 2.72 & 3.00 & 3.74 & 2.31 & 3.28 & 1.69 & 2.67 & 1.88 & 2.96 & 2.37 & 3.95 & 0.33 & 0.54 & 0.25 & 0.97 \\
\hline Exch. K $\left(\mathrm{cmol}_{\mathrm{c}} \mathrm{kg}^{-1}\right)$ & 0.67 & 1.45 & 1.74 & 2.19 & 0.57 & 1.74 & 0.73 & 1.46 & 0.51 & 0.93 & 0.54 & 2.83 & 0.41 & 0.72 & 0.65 & 2.30 \\
\hline Exch. $\mathrm{NH}_{4}-\mathrm{N}\left(\mathrm{cmol}_{\mathrm{c}} \mathrm{kg}^{-1}\right)$ & 0.20 & 0.22 & 0.24 & 0.35 & 0.31 & 0.35 & 0.06 & 0.11 & 0.13 & 0.31 & 0.10 & 0.15 & 0.09 & 0.18 & 0.07 & 0.14 \\
\hline Sum of exch. bases $\left(\mathrm{cmol}_{\mathrm{c}} \mathrm{kg}^{-1}\right)$ & 13.67 & 12.97 & 10.88 & 16.18 & 10.37 & 17.21 & 7.99 & 16.07 & 5.57 & 12.75 & 9.69 & 17.46 & 1.97 & 2.13 & 1.44 & 5.27 \\
\hline Avail. P (mg P kg $\left.{ }^{-1}\right)$ & 10.11 & 15.61 & 15.65 & 17.56 & 5.58 & 28.63 & 8.36 & 10.35 & 3.00 & 15.9 & 12.59 & 13.02 & 6.60 & 11.47 & 5.53 & 6.32 \\
\hline Al saturation (\%) & 0.2 & 0.2 & 0.3 & 0.1 & 0.3 & 0.5 & 0.4 & 0.2 & 13.8 & 0.2 & 0.3 & 0.3 & 30.7 & 19.9 & 34.1 & 0.8 \\
\hline \multicolumn{17}{|l|}{ Subsurface soil $(20-25 \mathrm{~cm})$} \\
\hline $\mathrm{pH}\left(\mathrm{H}_{2} \mathrm{O}\right)$ & 5.68 & 5.07 & 4.90 & 5.18 & 5.71 & 5.53 & 5.01 & 4.97 & 4.84 & 5.01 & 4.75 & 4.83 & 4.78 & 4.67 & 4.90 & 5.06 \\
\hline T-C $\left(\mathrm{g} \mathrm{kg}^{-1}\right)$ & 12.1 & 11.8 & 10.3 & 13.4 & 7.9 & 9.0 & 5.9 & 4.4 & 10.3 & 14.5 & 12.0 & 10.7 & 13.9 & 11.3 & 19.7 & 15.2 \\
\hline T-N $\left(\mathrm{g} \mathrm{kg}^{-1}\right)$ & 1.26 & 1.10 & 1.40 & 1.60 & 0.83 & 0.92 & 1.12 & 0.83 & 1.15 & 1.44 & 1.72 & 1.57 & 1.14 & 0.84 & 1.94 & 1.61 \\
\hline $\mathrm{C} / \mathrm{N}$ & 9.60 & 10.73 & 7.36 & 8.38 & 9.52 & 9.78 & 5.27 & 5.30 & 8.96 & 10.07 & 6.98 & 6.82 & 12.19 & 13.45 & 10.15 & 9.44 \\
\hline $\mathrm{CEC}\left(\mathrm{cmol}_{\mathrm{c}} \mathrm{kg}^{-1}\right)$ & 14.4 & 17.1 & 16.1 & 17.1 & 10.7 & 12.0 & 10.1 & 11.3 & 15.2 & 16.3 & 14.7 & 14.5 & 9.7 & 10.1 & 8.8 & 6.7 \\
\hline Exch. Ca $\left(\mathrm{cmol}_{\mathrm{c}} \mathrm{kg}^{-1}\right)$ & 3.26 & 5.00 & 1.54 & 7.73 & 3.61 & 4.62 & 1.64 & 2.21 & 1.59 & 1.96 & 1.39 & 3.48 & 0.27 & 0.53 & 1.36 & 0.65 \\
\hline Exch. $\mathrm{Mg}\left(\mathrm{cmol}_{\mathrm{c}} \mathrm{kg}^{-1}\right)$ & 1.30 & 1.49 & 1.59 & 2.07 & 1.46 & 1.67 & 1.12 & 1.21 & 1.36 & 1.10 & 0.96 & 1.17 & 0.02 & 0.10 & 0.36 & 0.38 \\
\hline Exch. K ( $\left.\mathrm{cmol}_{\mathrm{c}} \mathrm{kg}^{-1}\right)$ & 0.19 & 0.23 & 0.33 & 0.32 & 0.10 & 0.12 & 0.29 & 0.44 & 0.22 & 0.18 & 0.25 & 0.19 & 0.07 & 0.12 & 0.20 & 0.35 \\
\hline Exch. $\mathrm{NH}_{4}-\mathrm{N}\left(\mathrm{cmol}_{\mathrm{c}} \mathrm{kg}^{-1}\right)$ & 0.10 & 0.11 & 0.12 & 0.05 & 0.09 & 0.11 & 0.08 & 0.04 & 0.10 & 0.11 & 0.06 & 0.07 & 0.09 & 0.11 & 0.06 & 0.04 \\
\hline Sum of exch. bases $\left(\mathrm{cmol}_{\mathrm{c}} \mathrm{kg}^{-1}\right)$ & 4.76 & 6.75 & 3.54 & 10.17 & 5.19 & 6.43 & 3.10 & 3.88 & 3.19 & 3.25 & 2.64 & 4.89 & 0.37 & 0.77 & 1.95 & 1.39 \\
\hline Avail. P (mg P kg $\left.{ }^{-1}\right)$ & 2.99 & 1.61 & nil & 0.00 & 1.40 & 1.63 & nil & 1.51 & 0.94 & 0.95 & nil & 1.76 & 3.34 & 3.97 & 7.55 & 10.27 \\
\hline Al saturation (\%) & 5.5 & 22.7 & 29.4 & 6.2 & 8.2 & 4.9 & 31.0 & 26.8 & 40.5 & 36.9 & 39.5 & 26.1 & 78.8 & 65.7 & 35.2 & 39.8 \\
\hline
\end{tabular}

after burning due to the balance between the loss by heat decomposition at burning and the input of fuel residue. At the burning in 2004, the decrease in total carbon at MZ-D3 and MF-A5 represents 9.12 and $0.98 \mathrm{~g}$ $\mathrm{kg}^{-1}$ in surface soil, which could be the result of complete burning of above ground biomass in maize fields and medium fallow fields, respectively, based on the field observation. In contrast, total carbon increased by 6.34 and $3.15 \mathrm{~g} \mathrm{~kg}^{-1}$ at LF-A7 (long fallow) and MZ-A2 (maize field), respectively. It could be caused by the addition of unburned or partially burned plant materials (leaves and twigs). The increase in carbon and nitrogen were also observed in other shifting cultivation systems (Nye \& Greenland, 1964; Kyuma \& Pairintra, 1983; Tanaka et al. 2001). Burning results in partially carbonized litter which is probably added to the soil (Kyuma \& Pairintra, 1983). In some sites, the $\mathrm{C} / \mathrm{N}$ ratio tended to increase after burning (Table 7), indicating that fresh (partially carbonized) plant materials were added to the soil.

During burning in 2004, total nitrogen appeared to have the same pattern as total carbon in all sites. According to Table 7, total nitrogen content in the surface soil was increased $0.20-0.37 \mathrm{~g} \mathrm{~kg}^{-1}$ at site MZ-A2 and LF-A7, whereas total nitrogen was lost $0.14-1.08 \mathrm{~g} \mathrm{~kg}^{-1}$ at site MF-A5 and MZ-D3. The change in total nitrogen may not correspond to short-term change in $\mathrm{N}$ availability (Giardina et al. 2000).

Increase in the content of exchangeable $\mathrm{NH}_{4}-\mathrm{N}$ was observed especially in the first burning in 2004 . Judging from the facts that soil sampling after burning was conducted before fertilizer application, the increase in the $\mathrm{NH}_{4}-\mathrm{N}$ could be ascribed to heat decomposition process of soil organic matter and partial soil sterilization (Tulapitak et al. 1985). Similar results were observed in the previous studies on traditional shifting cultivation in northern Thailand (Tanaka et al. 2001) and northeastern Thailand (Tulapitak et al. 1985). Figure 4 and Table 7 show that the increase in the $\mathrm{NH}_{4}-\mathrm{N}$ by burning was small in the second burning compared to the first burning, suggesting the depletion of a nitrogen pool of soils available for heat decomposition and partial sterilization for the second cropping. After harvesting, the level of exchangeable $\mathrm{NH}_{4}-\mathrm{N}$ was low, especially in 2004 . These findings indicate severe depletion of the available 
nitrogen of the soils during cropping, even though significant amounts of $\mathrm{N}$ were applied as fertilizers during cropping. In addition, significant amounts of available phosphorus were supplied by burning practice (Table 8).

Soil pH of all sites after burning both at 2004 and 2005 increased irrespective of fallow length (Fig. 4). It is suggested that soil pH easily increased even by burning small amounts of biomass under short fallow or maize fields because of relatively high $\mathrm{pH}$ and relatively sandy texture of the soils. Burning caused a dramatic increase in the amount of exchangeable bases ( $\mathrm{Ca}, \mathrm{Mg}$, and $\mathrm{K}$ ). It should be noted that the $\mathrm{pH}$ after burning exceeded the average $\mathrm{pH}$ value at fruit tree plantations due to the addition of nutrients, especially basic cations from ash through burning (Table 3 and Fig. 4). Cation exchange capacity (CEC) can be affected by soil heating, but the influences varied (Giardina et al. 2000). The results shows CEC decreased after the first burning at all sites, whereas its level rose up after the second burning, which correlated with the content of total carbon $(r=0.86$, $\mathrm{P}<0.01$ ). Presumably, burning usually results in a wide variation of soil heating temperature within a field depending on burning time and aboveground biomass to be burned. The Al saturation in MZ-D3, where the level of the saturation before burning was relatively high, dropped dramatically by burning, but it increased during cropping.

The rapid decrease in soil $\mathrm{pH}$ and exchangeable bases and increase in $\mathrm{Al}$ saturation after harvesting suggested that the input of basic cations through ash and the successive fertilizer application was readily depleted due to uptake by crops and leaching from surface soils.

In Table 8, the changes in nutrients before and after burning are compared with the amount of fertilizer applied to the field during cropping. Because soil sampling after burning in each year preceded fertilizer application, the difference of soil nutrient levels before and after burning almost corresponded to the nutrient input through burning. The amounts of nutrients applied as a fertilizer were estimated based on the interview to the farmers. In addition, for reference, the table also shows nutrient input added by burning of tropical forest in northeast Thailand reported by Tulapitak et al. (1985). In this study, the release of $\mathrm{NH}_{4}-\mathrm{N}$ by burning to surface

Table 8. Nutrient added to the surface soil by burning and fertilizer application.

\begin{tabular}{|c|c|c|c|c|c|}
\hline \multirow[t]{2}{*}{ Nutrient } & \multirow[t]{2}{*}{ Site } & \multicolumn{2}{|c|}{$\begin{array}{l}\text { Input to surface layer } \\
\qquad\left(\mathrm{kg} \mathrm{ha}^{-1}\right)\end{array}$} & \multirow{2}{*}{$\begin{array}{l}\text { Nutrient added by } \\
\text { burning tropical forest } \\
\left(\mathrm{kg} \mathrm{ha}^{\mathrm{a}}\right)\end{array}$} & \multirow{2}{*}{$\begin{array}{c}\text { Fertilizing } \\
\text { per crop } \\
\left(\mathrm{kg} \mathrm{ha}^{-1}\right)\end{array}$} \\
\hline & & 1st burning & 2nd burning & & \\
\hline \multirow[t]{4}{*}{$\mathrm{N}$} & MZ-A2 & 3.4 & 14.9 & $20.6^{b}$ & 270.0 \\
\hline & MF-A5 & 5.3 & 7.7 & & 270.0 \\
\hline & LF-A7 & 21.9 & 5.8 & & 168.8 \\
\hline & MZ-D3 & 11.6 & 8.7 & & 168.8 \\
\hline \multirow[t]{4}{*}{$\mathrm{P}$} & MZ-A2 & 4.0 & 10.2 & 50.8 & 21.8 \\
\hline & MF-A5 & 17.7 & 14.8 & & 21.8 \\
\hline & LF-A7 & 8.7 & 26.6 & & 13.6 \\
\hline & MZ-D3 & 3.6 & 14.9 & & 13.6 \\
\hline \multirow[t]{4}{*}{$\mathrm{K}$} & MZ-A2 & 217.4 & 125.4 & 290 & nil \\
\hline & MF-A5 & 354.0 & 219.5 & & nil \\
\hline & LF-A7 & 108.7 & 604.8 & & nil \\
\hline & MZ-D3 & 87.2 & 473.9 & & nil \\
\hline \multirow[t]{4}{*}{$\mathrm{Ca}$} & MZ-A2 & -254.1 & 592.2 & 1933 & 5.4 \\
\hline & MF-A5 & 726.0 & 982.8 & & 5.4 \\
\hline & LF-A7 & 769.4 & 525.9 & & 3.4 \\
\hline & MZ-D3 & -51.4 & 213.1 & & 3.4 \\
\hline \multirow[t]{4}{*}{$\mathrm{Mg}$} & MZ-A2 & 25.3 & 65.1 & 114 & 3.0 \\
\hline & MF-A5 & 90.3 & 91.8 & & 3.0 \\
\hline & LF-A7 & 88.3 & 130.3 & & 1.9 \\
\hline & MZ-D3 & 18.6 & 64.5 & & 1.9 \\
\hline
\end{tabular}

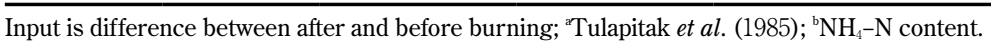


soil was less than $15 \mathrm{~kg} \mathrm{ha}^{-1}$. This amount seemed to be insufficient to support crop growth, compared with fertilization rates of $168-200 \mathrm{~kg} \mathrm{ha}^{-1}$. It is suggested that the application of nitrogen fertilizer is indispensable under the intensified shifting cultivation system. The amount of phosphorus added from burning was almost equivalent to that from fertilizer application. In contrast, the input of potassium, calcium, and magnesium from the ash through burning was significant and seemed to be sufficient for crop growth even without fertilizer application. Thus, our study on the intensified shifting cultivation found that burning of aboveground biomass can still have important effects to improve surface soil acidity and to supply basic cations into the soils while application of nitrogen fertilizer is required as a major external source of nitrogen. However, in most cases, the effects of ash addition and fertilizer application were short-lived. Large amount of nitrogen, in particular, which relied on the external fertilizer application, seemed to be lost from the soils during cropping, indicating the possibility of environment and water pollution. It is imperative to develop appropriate fertilizing method to prevent a loss of nitrogen from soil ecosystems.

\section{CONCLUSIONS}

This study characterized soil fertility level under the intensified shifting cultivation system currently conducted in the Lower Northern Thailand. Soil fertility levels in the study area depended largely on locations. However, although no clear differences were observed in most of the soil properties in terms of land use types, several soil properties could be related to the land use types: The soil acidity was high under fallow in Location $B$ while the soils under bamboo in the medium fallow showed higher levels of soil fertility. In contrast, several soils under maize or fruit tree plantation showed very low content of soil organic matter, suggesting occurrence of soil degradation in terms of organic matter.

Burning practices, even though it was second burning with a small amount of biomass, affected soil fertility levels and brought positive effects to the soil fertility in terms of alleviation of soil acidity and supply of exchangeable basis and available phosphorus. Taking into account of relatively small input of basic cations and phosphorus from fertilizer application, burning of biomass even from a relatively short fallow is significant for continuous cropping under the current intensified shifting cultivation systems. In contrast, the level of available nitrogen must be maintained by fertilizer application.

To conserve soil environment and develop sustainable agricultural systems, the further study on soil fertility should be carried out both in short term and long term perspectives: for short term, nutrient dynamics must be studied in more detail in terms of land use types and burning practices within one location to prevent nutrient loss from soil ecosystems and maintain soil fertility levels. On the other hand, to provide long-term agricultural strategies, the potentials of soil productivity must be assessed taking into account topographic conditions and parent materials that are key factors to determine soil fertility levels principally.

ACKNOWLEDGEMENTS This study was supported by the Japanese Government (Monbukagakusho) Scholarship program. We thank Pooriputt Boonyanuphap, Poochan Saisangsom, and Sunisa Sukneam for their help with field work. We also sincere thank the Thung Saleang Luang National Park Office and Naresuan University for the assistance and support during this study.

\section{REFERENCES}

Bruijnzeel, L.A. 1991. Nutrient input-output budgets of tropical forest ecosystems: a review. Journal of Tropical Ecology, 7: 1-24.

Christanty, L., Kimmins, J.P. \& Mailly, D. 1997. Without bamboo, the land dies: A conceptual model of the biogeochemical role of bamboo in an Indonesian agroforestry system. Forest Ecology and Management, 91: 83-91.

Funakawa, S., Tanaka, S., Kaewkhogkha, T., Hattori, T. \& Yonebayashi, K. 1997a. Physicochemical properties of the soils associated with shifting cultivation in Northern Thailand with special reference to factors determining soil fertility. Soil Science and Plant Nutrition, 43: 665-679.

Funakawa, S., Tanaka, S., Kaewkhogkha, T., Hattori, T. \& Yonebayashi, K. 1997b. Ecological study on the dynamics of soil organic matter and its properties in shifting cultivation systems of Northern Thailand with special reference to factors determining soil fertility. Soil Science and Plant Nutrition, 43: 681-693.

Gee, G.E. \& Bauder, J.W. 1986. Particle-size Analysis. In: Method of soil analysis. Part 1-Physical and Mineralogical Methods (eds. Klute, A., Campbell, G.S., Jackson, R.D., Mortland, M.M. \& Nielsen, 
D.R.), pp. 399-404. Soil. Sci. Soc. America, Inc. and American Soc. Agronomy, Inc., Madison, Wisconsin. Giardina, C.P., Sanford, Jr.R.L., Døckersmith, I.C. \& Jaramillo, V.J. 2000. The effect of slash burning on ecosystem nutrients during the land preparation phase of shifting cultivation. Plant and Soil, 200: 247-260.

Haynes, R.J. \& Mokolobate, M.S. 2001. Amelioration of Al toxicity and $\mathrm{P}$ deficiency in acid soils by additions of organic residues: a critical review of the phenomenon and the mechanisms involved. Nutrient Cycling in Agroecosystems, 59: 47-63.

Juo, A.S.R. \& Manu, A. 1996. Chemical dynamics in slash-and-burn agriculture. Agricultural Ecosystem \& Environment, 58: 49-60.

Kendawang, J.J., Tanaka, S., Shibata, K., Yoshida, N., Sabang, J., Ninomiya, I. \& Sakurai, K., 2005. Effect of shifting cultivation on soil ecosystems in Sarawak, Malaysia. III Results of burning practice and changes in soil organic matter at Niah and Bakam. Soil Science and Plant Nutrition, 51: 515-523.

Kunstadter, P., Charpman, E.C. \& Sabhasri, S., 1978. Farmers in the Forest: Economic Development and Marginal Agriculture in Northern Thailand. Honolulu, The University Press of Hawaii. 393 pp.

Kuo, S. 1996. Phosphorus. In: Method of soil analysis. Part 3-Chemical Methods (eds. Sparks, D.L. Page, A.L. Helmke, P.A., Loeppert, R.H., Soltanpour, P.N., Tabatabai, M.A., Johnston, C.T. \& Sumner, M.E.), pp. 869-919. Soil. Sci. Soc. America, Inc. and American Soc. Agronomy, Inc., Madison, Wisconsin.

Kyuma, K. \& Pairintra, C. 1983. Shifting cultivation: An Experiment at Nam Phrom, Northeast Thailand, and Its Implications for Upland Farming in the Monsoon Tropics. Kyoto, Faculty of Agriculture, Kyoto University. Kyoto. 219 pp.

Land Development Department, 1998. Soil Resource Management Report for in the Lowland Area [CD-ROM]. Land Development Department. Ministry of Agriculture and Cooperatives. Bangkok.

Mulvaney, R.L. 1996. Nitrogen-Inorganic forms. In: Method of soil analysis. Part 3-Chemical Methods (eds. Sparks, D.L. Page, A.L. Helmke, P.A., Loeppert, R.H., Soltanpour, P.N., Tabatabai, M.A., Johnston, C.T. \& Sumner, M.E.), pp. 1123-1184. Soil. Sci. Soc. America, Inc. and American Soc. Agronomy, Inc., Madison, Wisconsin.

Nakano, K. 1978. An ecological study of swidden agriculture at a village in northern Thailand. South East Asian Studies, 16: 411-446.
Nye, P. \& Greenland, D. 1960. The soil under shifting cultivation. Technical Communication No. 51. Commonwealth Agricultural Bureau, England. 156 pp.

Putthacharoen, S., Howeler, R.H., Jantawat, S. \& Vichukit, V. 1998. Nutrient uptake and soil losses in cassava and six other crops in a Psament in eastern Thailand. Field Crops Research, 57: 113-126.

Sanchez, P.A. 1995. Science in agroforestry. Agroforestry Systems, 30: 5-55.

Soil Survey Staff. 1999. Keys to Soil Taxonomy. Pocahontas Press Inc., Blacksburg, Virginia. 599 pp.

Stromgaard, P. 1984. The immediate effect of burning and ash-fertilization. Plant and Soil, 80: 307-320.

Tanaka, S., Funakawa, S., Kaewkhogkha, T., Hattori, T. \& Yonebayashi, K. 1997. Soil ecological study on dynamics of $\mathrm{K}, \mathrm{Mg}$, and $\mathrm{Ca}$, and soil acidity in shifting cultivation in Northern Thailand. Soil Science and Plant Nutrition, 43: 695-708.

Tanaka, S., Funakawa, S., Kaewkhogkha, T. \& Yonebayashi, K. 1998a. Labile pools of organic matter and microbial biomass in the surface soil under shifting cultivation in Northern Thailand. Soil Science and Plant Nutrition, 44: 527-537.

Tanaka, S., Funakawa, S., Kaewkhogkha, T. \& Yonebayashi, K. 1998b. N mineralization process of the surface soils under shifting cultivation in Northern Thailand. Soil Science and Plant Nutrition, 44: 539-549.

Tanaka, S., Ando, T., Funakawa, S., Sukhrun, C., Kaewkhogkha, T. \& Sakurai, K. 2001. Effect of burning on soil organic mater content and $\mathrm{N}$ mineralization under shifting cultivation system of Karen people in Northern Thailand. Soil Science and Plant Nutrition, 47: 547-558.

Tanaka, S., Kendawang, J.J., Yoshida, N., Shibata, K., Jee, A., Tanaka, K., Ninomiya, I. \& Sakurai, K. 2005. Effect of shifting cultivation on soil ecosystems in Sarawak, Malaysia. IV. Chemical properties of the soils and runoff water at Niah and Bakam. Soil Science and Plant Nutrition, 51: 525-533.

Tanasombat, M., Okabayashi, Y., Sakurai, K., Thaiutsa, B., Thammincha, S. \& Suekeaw, P. 2005. Silvicultural performance of paper mulberry in Thailand. Tropic, 14: $149-162$.

Thai Meteorological Department 2002. Weather data 1992-2002. Thai Meteorological Department., Bangkok.

Tulapitak, T., Pairinta, C. \& Kyuma, K. 1985. Change in soil fertility and tilth under shifting cultivation II. 
Changes in soil nutrient status. Soil Science and Plant Nutrition, 31: 239-249.

Vågen, T.G., Andrianorofanomezana, M.A.A. \& Andrianorofanomezana, S. 2006. Deforestation and cultivation effects on characteristics of oxisols in the highlands of Madagascar. Geoderma, 131: 190-200.

Received $4^{\text {th }}$ Sep. 2006

Accepted $4^{\text {th }}$ Oct. 2006 


\section{Appendix}

\begin{tabular}{llll}
\hline Site & Horizontal & Depth $(\mathrm{cm})$ & Description \\
\hline DEF11 & A & $0-5$ & Brown to dark brown (10YR4/6 dry, 10YR3/4 wet) clay; strong fine subangular \\
& & $\begin{array}{l}\text { blocky structure; extremely hard, sticky, plastic; medium organic matter; } \\
\text { common roots; dry moisture condition; abrupt, smooth boundary; } 20 \text { mm of } \\
\text { hardness. }\end{array}$
\end{tabular}

$\mathrm{AB} \quad 5-13 \quad$ Brown (10YR4/6 dry, 7.5YR4/4 wet) light clay; strong fine subangular blocky structure; friable, very sticky, plastic; low organic matter; common roots; slightly moist condition; clear, smooth boundary; $23 \mathrm{~mm}$ of hardness.

BA 13-29 Brown (10YR4/6 dry, 7.5YR4/4 wet) light clay; strong fine subangular blocky structure; friable, very sticky, plastic; low organic matter; common roots; slightly moist condition; clear, smooth boundary; $23 \mathrm{~mm}$ of hardness.

B1 29-40 Bright brown to brown (7.5YR5/6 dry, 7.5YR5/6 wet) heavy clay; strong fine to medium subangular blocky structure; friable, very sticky, plastic; low organic matter; very few roots; slightly moist condition; clear, smooth boundary; $30 \mathrm{~mm}$ of hardness.

B2 40-60 Bright brown (7.5YR5/6 dry, 7.5YR4/4 wet) heavy clay; many medium distinct mottles of dull brown to brown (7.5YR5/4 and 7.5YR4/6); few, fine, subangular, strong weathering of rock fragment; strong fine to medium subangular blocky structure; firm, very sticky, plastic; low organic matter; very few roots; slightly moist condition; clear, smooth boundary; $30 \mathrm{~mm}$ of hardness.

BC 60-80+ Bright brown (7.5YR5/6 dry, 7.5YR4/4 wet) heavy clay; many medium distinct mottles of dull brown to brown (7.5YR5/4 and 7.5YR4/6); many, fine, subangular, strong weathering of rock fragment; strong fine to medium subangular blocky structure; extremely firm, very sticky, plastic; low organic matter; very few roots; slightly moist condition; $30 \mathrm{~mm}$ of hardness.

DEF13 A $\quad 0-5 \quad$ Dark brown to brownish black (7.5YR3/4 dry, 7.5YR3/2 wet) loam; strong fine subangular blocky structure; friable, slightly sticky, plastic; medium organic matter; common roots; slightly moist condition; abrupt, wavy boundary; $25 \mathrm{~mm}$ of hardness

$\mathrm{AB} \quad 5-20 \quad$ Brown (7.5YR4/4) clay loam; strong fine subangular blocky structure; friable, sticky, plastic; low organic matter; few roots; slightly moist condition; abrupt, wavy boundary; $23 \mathrm{~mm}$ of hardness

B1 20-30 Bright brown (7.5YR5/8) clay loam; strong fine subangular blocky structure; friable, sticky, plastic; low organic matter; few roots; slightly moist condition; abrupt, smooth boundary; $25 \mathrm{~mm}$ of hardness.

B2 30-40 Bright brown (7.5YR5/8) light clay; strong very fine subangular blocky structure; friable, sticky, plastic; very low organic matter; few roots; slightly moist condition; clear, smooth boundary; $25 \mathrm{~mm}$ of hardness.

B3 $40-60$

Bright reddish brown (5YR5/8) light clay; moderate fine subangular blocky structure; friable, sticky, plastic; very low organic matter; few roots; slightly moist condition; clear, smooth boundary; $20 \mathrm{~mm}$ of hardness.

B4 60-100+ Reddish brown (2.5YR4/6) heavy clay; moderate fine subangular blocky structure; friable, very sticky, very plastic; very low organic matter; few roots; moist condition; clear, smooth boundary; $22 \mathrm{~mm}$ of hardness. 